\title{
Multi-Objective Optimization of an Integrated Algal and Sludge-Based Bioenergy Park and Wastewater Treatment System
}

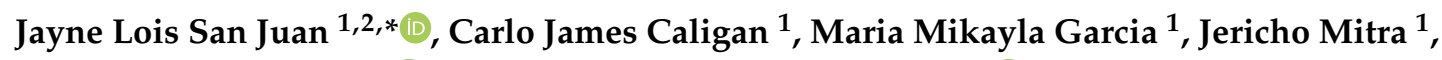 \\ Andres Philip Mayol 2,3(D), Charlle Sy ${ }^{1,2}$, Aristotle Ubando ${ }^{2,3}\left(\mathbb{D}\right.$ and Alvin Culaba ${ }^{2,3}$ \\ 1 Industrial Engineering Department, De La Salle University, Manila 0922, Philippines; \\ carlo_caligan@dlsu.edu.ph (C.J.C.); maria_mikayla_garcia@dlsu.edu.ph (M.M.G.); \\ jericho_mitra@dlsu.edu.ph (J.M.); charlle.sy@dlsu.edu.ph (C.S.) \\ 2 Center for Engineering and Sustainable Development Research, De La Salle University, \\ Manila 0922, Philippines; andres_mayol@dlsu.edu.ph (A.P.M.); \\ aristotle.ubando@dlsu.edu.ph (A.U.); alvin.culaba@dlsu.edu.ph (A.C.) \\ 3 Mechanical Engineering Department, De La Salle University, Manila 0922, Philippines \\ * Correspondence: jayne.sanjuan@dlsu.edu.ph
}

Received: 20 August 2020; Accepted: 16 September 2020; Published: 21 September 2020

\begin{abstract}
Given increasing energy demand and global warming potential, the advancements in bioenergy production have become a key factor in combating these issues. Biorefineries have been effective in converting biomass into energy and valuable products with the added benefits of treating wastewater used as a cultivation medium. Recent developments enable relationships between sewage sludge and microalgae that could lead to higher biomass and energy yields. This study proposes a multi-objective optimization model that would assist stakeholders in designing an integrated system consisting of wastewater treatment systems, an algal-based bioenergy park, and a sludge-based bioenergy park that would decide which processes to use in treating wastewater and sludge while minimizing cost and carbon emissions. The baseline run of the model showed that the three plants were utilized in treating both sludge and water for the optimal answer. Running the model with no storage prioritizes water disposal, while having storage can help produce more energy. Sensitivity analysis was performed on storage costs and demand. Results show that decreasing the demand is directly proportional to the total costs while increasing it can help reduce expected costs through storage and utilizing process capacities. Costs of storage do not cause a huge overall difference in costs and directly follow the change.
\end{abstract}

Keywords: multi-objective optimization; bioenergy; biomass; microalgae; sludge; wastewater

\section{Introduction}

As global energy consumption continuously increases over time due to economic and population growth, fossil fuel utilization persists to be a prominent contributor to meeting the ever-increasing energy demand. Oil, coal, and natural gas have consistently remained the top 3 energy sources by a significant amount from 1990 to 2017 [1]. Greenhouse gas emissions from the use of fossil fuels pose a threat to the environment, as they are a primary factor in global warming [2]. Moreover, the nonrenewable nature of fossil fuels poses a threat to the sustainability of traditional energy practices. As such, interest in finding renewable alternative sources of energy that can compete with fossil fuels in terms of performance while having less environmental impact has become prevalent in recent years [3].

Biofuels, such as biodiesel and bioethanol, are potential alternatives as they are derived from renewable biomass and generate less emissions. Biorefineries have been highly utilized in converting 
biomass into renewable energy and other bio-products. Microalgal biomass is highly regarded for biofuel production in terms of its performance, product outputs, and environmental benefits. However, challenges regarding its high investment and processing costs make it particularly difficult to adopt commercially [4]. Downstream processes, excluding cultivation, make up $60 \%$ of the total production cost [5]. Different alternatives per process exhibits varying costs, environmental damage, and output quality that need to be considered in designing an algal-based biorefinery. Integrating a wastewater treatment system with algal cultivation has gained increasing interest. Wastewater contains the necessary nutrients for algae growth, which makes it a viable cultivation medium and wastewater treatment alternative. This lowers the cultivation medium costs of microalgal-based biofuel production, increasing its economic feasibility [6].

Wastewater treatment is an essential process in society due to the contaminants within wastewater generating significant health and environmental risks when left untreated. Waste generation has been continually increasing with population growth, thus requiring more and more wastewater to be treated [7]. Utilizing the different treatment processes inherently produces sewage sludge that is first treated then disposed of. Conventional treatment and disposal methods however do not take advantage of the energy generating capabilities present within wastewater sludge that can benefit the system economically and environmentally. Oladejo et al. [8] reviewed the different conversion methods in recovering energy from sludge. Tradeoffs such as cost, environmental impact, operational capacity, quality limit, bio-product yield, and energy yield of each conversion route presents the importance of resource management, process utilization, and decision making in sludge-to-energy recovery methods.

Bioenergy parks are known facilities that can convert biomass resources into valuable products such as biofuels and power [9]. This allows exchanges of materials between bioenergy plants in maximizing the use of bioenergy products, by-products, and wastes. Exchanges between microalgae and sludge bioenergy parks have been explored in several studies that present beneficial results. Wang et al. [10] determined that the co-pyrolysis of sewage sludge and microalgae yielded greater bio-oil than individual pyrolysis of sludge. On the other hand, Mahdy et al. [11] co-digested sludge and microalgae, which resulted in a higher methane yield compared to the substrates individually digested. Chen et al. [12] explored the utilization of sludge digestate with wastewater in microalgae cultivation, which reduces the total costs of the integrated system. However, it is important to note that using both sludge and microalgae in a given bioenergy production process will require a certain amount of pretreatment before fully realizing the benefits.

The integration of a wastewater treatment system, algal-based bioenergy park, and sludge-based bioenergy park forms a closed-loop system that considers different alternatives in treating water and managing imminent waste, energy, and environmental problems. The connected system can select different options in accommodating varying inputs of wastewater volume and the potential biomass derived from its treatment. Utilizing the biomass produced for energy production would provide a multitude of benefits, as it could bring in profit when sold in the market and reduce environmental impacts through greenhouse gas emission savings. Mathematical models applied on this network can produce insights on the necessary processes to be used, considering both economic and environmental factors that may be beneficial to actual systems that are similar in nature. The proposed study would be an optimization model on the integrated network between wastewater treatment systems and microalgae and sludge bioenergy park focusing, which could be used by stakeholders in planning out the necessary processes to use on the treatment of wastewater and sludge. The study can also encourage wastewater treatment providers to consider finding alternative processes aside from the traditional treatment of water and sludge that could satisfy proper disposal requirements while providing long-term benefits in terms of cost and emissions.

\section{Review of Related Literature}

The use of mathematical models has been utilized in designing wastewater treatment systems to find the optimal network of operations [13]. This has been adopted in studies in providing adequate 
treatment for the influent, while avoiding any unnecessary processes. Tsai et al. [14] developed a decision-making framework in handling the incoming wastewater in the system. With the use of dynamic programming, the study focused on minimizing the economic cost incurred in a wastewater treatment system, while adhering to the constraints set to the final disposal limits for both water and sludge. The study was able to show the technologies that should be adopted in the treatment facility that would ensure cleanliness of the effluent while minimizing economic cost. The study, however, was not able to consider the bioenergy generated in the treatment of sludge, which can further reduce the overall cost of the system. Kim et al. [15] further extended the scope of the study by applying a multi-objective optimization model on wastewater treatment systems that minimizes cost, greenhouse emissions, and pollution from the disposed effluent. Using multi-objective optimization is done when two or more naturally conflicting objectives are considered to find an optimal solution that would not optimize one target at the expense of others. Rather, it would find a solution that would find the balance for all objectives. In comparison with the former study, a fixed pathway for sewage and sludge treatment was established to accommodate the incoming wastewater. The research was able to determine the process configurations of the plant including the flow rates, dissolved oxygen concentration, operating temperature, and decision on whether to use sludge biomass as a biogas.

Ang et al. [16] developed a mathematical model by considering different input configurations for the incoming wastewater, multiple available treatment processes, and different disposal and reuse options. Processes in the wastewater treatment facility were optimized using a non-linear programming model that considers both economic cost and adverse environmental impacts from the quality of effluent discharged. They tested the changes in the behavior in the model by adding other disposal and reuse options compared to the initial scenario wherein one disposal option was available and found that the wastewater would need to undergo different pathways to maintain optimality.

Although proven effective in treating wastewater, traditional wastewater treatment facilities still face its major issue of high greenhouse emissions from its processes [17]. Given this scenario, interests in sustainable bioenergy parks as alternatives in water and sludge treatment are continuously rising. These facilities must adopt long-term design and capacity planning to become a sustainable project that could gradually replace fossil fuel consumption and take up more energy market share [4]. The use of mathematical models has been found to be efficient in the design of bioenergy parks into sustainable systems $[18,19]$. These studies are mostly concerned with handling biomass using various processing technologies with respect to cost and environmental performance.

As such, a comprehensive review shows that microalgae bioenergy parks are mainly concerned with the selection of cultivation systems, harvesting techniques, and conversion processes of microalgae into bioenergy [20]. A mathematical model developed by Gupta et al. [21] aims to minimize the cost of processes for the microalgae biorefinery while satisfying the demand for biodiesel in the market. The study established a fixed cultivation system, harvesting, and conversion process and was able to find the best design for the microalgae processes including the capacity of the tanks, microalgae growth medium, and growth duration. The study focused on fulfilling the bioenergy demand, although it failed to consider the revenue obtained from selling the products, which could substantially improve the economic cost. It also limited the cultivation system and harvesting option. Hoeltz et al. [22] reviewed the whole microalgae process and found different tradeoffs for cultivation systems and harvesting options in terms of biomass productivity, operating cost, and water quality while Ong et al. [23] considered different biomass conversion processes to energy that fundamentally vary in biodiesel yield and operating cost.

Garcia-Preto et al. [24] designed an algal biorefinery to produce different kinds of biofuels focusing on the economic aspect of using the processes in a multi-period horizon. The model was able to find the best cultivation system and conversion process of microalgae into biodiesel, astaxanthin, and polyhydroxy butyrate with considerations of investment costs, operating costs, land requirements, and revenue for selling the products to ensure economic feasibility. 
Culaba et al. [25] developed an optimization model focusing on the biofuel production aspect of microalgae biomass that can help in investment planning and operational and expansion decisions. The study was able to consider both the objective of maximizing net present value and minimizing greenhouse gas emission. They were able to show the connections that the biomass would need to undergo and material streams for the inputs to optimize biofuel production. Solis et al. [26] made a similar study utilizing a life cycle assessment methodology for the algal biorefinery to properly consider the carbon footprint of the processes done. The study was able to show which processes are utilized when either cost or environmental impact was optimized and when both objectives were optimized simultaneously. It was shown that different connections were formed with the consideration of different objectives.

A different approach was used by Caligan et al. [27] by integrating an algal biorefinery plant and wastewater treatment plant through a multi-objective optimization model that considers both cost and environmental impact aspects of the system. Wastewater may be treated by a wastewater treatment plant, algal biorefinery plant, or both plants to reach water quality requirements before disposal. Utilizing the biorefinery plant means selecting the proper cultivation system and harvesting option of microalgae, which will be used as biomass for energy production which could either be sold or used in running the facilities to reduce overall expenses. The study was able to show the connection of the processes in both facilities that can be used to treat the wastewater and handle microalgae biomass. With the consideration of the two objectives, both facilities were utilized in treating wastewater to find a balance between the two objectives.

Sludge treatment systems have also been found in the literature. Mathematical models on wastewater treatment plants have considered handling the accumulated sludge; however, they limit sludge handling to a default treatment process $[14,15]$. The quality of the digestate is not considered in those studies. Providing multiple alternatives for sludge treatment may be added to account for the unpredictability of the quality of incoming sludge. Sludge-to-energy systems are becoming significant in the field of research due to the high potential of sludge as biomass feedstock for energy production. As such, Cao and Pawlowski [28] introduced anaerobic digestion and pyrolysis processes for sewage sludge treatment in the study. Anaerobic digestion of sewage sludge has been the most common process in sludge treatment since it is cost-efficient and results in biogas production. However, this process is not able to fully utilize the organic matters in sludge compared to in pyrolysis. Pyrolysis, on the other hand, provides higher bioenergy production, although its use would incur higher operating cost. Depending on the quality and quantity of the sludge, different choices may be optimal for its treatment.

Different sludge handling approaches that provide treatment as well as generate energy were presented by Mills et al. [29]. Different sets of anaerobic digestion and pyrolysis processes were included and showed their respective energy flows and product. Lam et al. [30] extended the aforementioned study by developing a life-cycle data envelopment analysis on available technologies used by different facilities. The study included aerobic digestion, anaerobic digestion, and incineration as the main sludge treatment processes. The efficiency of the processes was evaluated based on multiple performance metrics which include volatile solids reduction, energy generation, chemical consumption, energy use and recovery, sludge residue generation, and environmental impact. Both aerobic and anaerobic digestion were able to reduce the volatile solids content of sludge; however, neither aerobic digestion nor anaerobic digestion are not as effective as the incineration process. Incineration was able to show high volatile solids reduction and sludge reduction, though it consumed higher energy and resulted in more adverse impacts to the environment. The aforementioned studies regarding sludge treatment, however, were mostly experimental and do not provide the best options to be used for different scenarios.

Vadenbo et al. [31] developed a mixed-integer linear programming for waste incineration which considered both economic and environmental impact objectives. With the consideration of multiple activities, incineration configurations, materials, and the final product, the model was able to optimize the system configuration by providing the best choices based on the established objective. This study, 
however, is only focused on the incineration process, which may not always be the best treatment to be used for the sludge produced.

The use of pyrolysis and incineration processes, compared to other stabilization processes, generally requires low moisture content to increase the efficiency of the processes and reduce the generation of non-condensable gases [32,33]. Therefore, the sludge is usually subjected to dewatering and drying processes before being processed in these kinds of treatments.

Though recent works have generally been efficient in planning and designing each of the facilities separately, they were not able to analyze their scope from a system perspective since not all factors and relationships were considered. Some studies on wastewater treatment systems were not able to take into consideration the sludge by-product generated in the processes used. Relevant studies, particularly on sludge were mostly experimental studies focusing on the evaluation of different available technologies and providing possible configurations to be implemented by the facilities. These studies did not intend to optimize the processes and hence did not always meet particular targets and constraints for their outputs. The application of optimization models assures us that the design has reached the optimal solution in terms of the objectives specified while meeting all the targets and constraints.

To date, no optimization model has been done considering an integrated network of wastewater treatment and bioenergy production from microalgae and sludge. The proposed model will be able to determine the best treatment and conversion processes to select that would minimize both economic cost and carbon emission depending on the wastewater demand.

\section{Network Definition}

An overview of the integrated wastewater treatment system (WTS), sludge bioenergy park (SBP), and microalgae bioenergy park (MBP) network is shown in Figure 1. The scope of the system would begin with the input of wastewater to either the WTS or MBP and end in the reuse and disposal of treated wastewater. The system would accept various wastewater sources that are generally found in wastewater systems including industrial wastewater, municipal wastewater, and stormwater runoffs [34]. The accommodated input would have varying contents in terms of volume and constituent concentrations. The WTS would consist of different treatment options, with each having distinct treatment rates for each quality type and generating different characteristics of sewage sludge. The accumulated sludge will be sent to the SBP for sludge treatment. The network would utilize a mixed input configuration in which the entering input in a treatment process would result in an aggregate quality level for the mixture that will serve as a basis for quality improvement. Once done, the output may either go through succeeding treatment options available or be disposed of afterwards if the quality of the effluent has satisfied the requirements for disposal. It may enter the MBP for additional treatment, if necessary, to comply with the requirements.

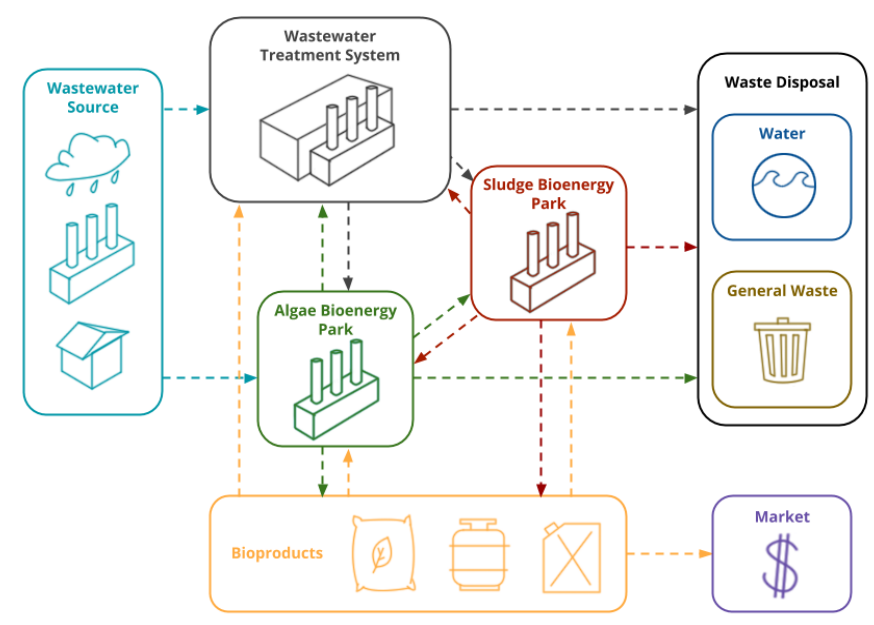

Figure 1. Network Diagram. 
The MBP would use wastewater as a medium for growing microalgae in a cultivation system. The microalgae will utilize the contents of the water as nutrients for growth, which in return will serve as a treatment to the water by removing any undesirable contents that are present. It may also be mixed with fresh water to balance the mixture when the contaminant concentrations are deemed undesirable for microalgae growth. Cultivation systems, or the containers used for growing microalgae, are classified as open and closed systems. Digested sludge coming from the sludge bioenergy park can also be sent to the cultivation system in the MBP to increase algal biomass production [35]. The microalgae produced are then collected through different harvesting techniques, which can have varying results in terms of cost and algal biomass yield. The water used as a medium is then disposed of or stored for additional treatment in the following period if necessary. The collected algal biomass then proceeds to the conversion stage where different options are available for generating various bioenergy products.

The SBP is concerned with handling the sludge produced in the WTS, which would initially enter the thickening stage for volume reduction. Thickened sludge may be selected from different stabilization processes available for treatment that may vary in terms of cost, sludge treatment rate, and gas emissions. Using the digestion process for stabilization is also known to produce methane that can be used for energy production [36]. Sludge may also bypass the stabilization stage if advanced treatments are necessary to further remove organic matters and other undesirable contents in sludge, as well as for producing better bioenergy products. Microalgae biomass from the algae bioenergy park can be brought to energy generating processes in the stabilization and advanced treatment stages to be combined with sewage sludge to boost bioenergy production. Treated sludge is then disposed of from the facility and is brought to landfill sites.

Multi-objective optimization has been widely utilized in analyzing and optimizing complex systems including industrial symbiosis and process integration. In particular, the use of mixed integer nonlinear programming (MINLP) models has been applied in optimization studies for designing huge systems such as bioenergy parks and wastewater treatment systems with consideration of economic and environmental aspects $[15,16]$. This will be used in finding the best connections and material exchanges between facilities. Adopting multi-objective optimization is appropriate for fully capturing both economic costs and environmental impacts simultaneously. This is because focusing on only aspect of a model compromises the other aspects and neglects the tradeoff that exists between the objectives. The goal programming approach has been efficient in previous multi-objective optimization studies in achieving a solution that balances the two objectives [37]. This methodology will be utilized to find the balance between the two objectives considered.

A multi-period system is adopted in the model to recognize the difference in treatment routes to be utilized for sludge and water for dealing with the uncertainty of wastewater demand and quality. The objective components considered by the system would include both costs and environmental impacts. The total economic cost would consist of the operating costs of utilized processes, holding cost of storage use, and disposal cost of the treated water and sludge into output sites. Potential savings and profit from the energy produced by both sludge and microalgae feedstocks are deducted in the cost component. On the other hand, carbon emissions produced from the processes used and disposal in landfill sites are concerned with the environmental considerations in the model. Greenhouse emission savings for the use of the renewable energies generated will be considered.

\section{Model Formulation}

A mixed integer nonlinear programming model (MINLP) was formulated for the network integrating the three facilities with the goal of finding operational decisions in treating the wastewater demand and handling sludge and algal biomass. This methodology would be able to simultaneously minimize cost and environmental objectives while considering the available treatment processes water and biomass, capacity constraints, disposal options for the treated water and sludge, and market prices of potential bioproducts produced in a bioenergy park. 


\subsection{Model Nomenclature}

Table 1 shows the indices, decision variables, and parameters used in formulating the model.

Table 1. Notations.

\begin{tabular}{clrl}
\hline & & Indices & \\
\hline $\mathrm{i}$ & Input Type & $\mathrm{t}$ & Time Period \\
$\mathrm{j}$ & Cultivation System & $\mathrm{s}$ & Stabilization Process \\
$\mathrm{k}$ & Wastewater Treatment Process & $\mathrm{a}$ & Advanced Treatment Process \\
$\mathrm{e}$ & Algae Conversion Process & $\mathrm{b}$ & Bioproduct \\
$\mathrm{m}$ & Quality Type & 1 & Sludge Disposal Site \\
$\mathrm{n}$ & Harvesting Type & $\mathrm{d}$ & Bioproduct to be sold or reused \\
$\mathrm{o}$ & Output site & & \\
\hline
\end{tabular}

Decision Variables

$\mathrm{U}_{\mathrm{ikt}} \quad$ Volume of water type $\mathrm{i}$ to enter WTS process $\mathrm{k}$ at time period $\mathrm{t}$

$V_{\mathrm{ijt}} \quad$ Volume of water type $\mathrm{i}$ to enter cultivation system $\mathrm{j}$ at time period $\mathrm{t}$

se $_{i t} \quad$ Volume of water type $i$ to be stored at time period $t$

$\mathrm{P}_{\mathrm{kkt}} \quad$ Volume of water in WTS from treatment process $\mathrm{k}$ to process $\mathrm{k}$ at time period $\mathrm{t}$

$\mathrm{stw}_{\mathrm{kt}} \quad$ Volume of water from storage to treatment process $\mathrm{k}$ at time period $\mathrm{t}$

$\mathrm{Y}_{\mathrm{kot}} \quad$ Binary, 1; water coming from process $\mathrm{k}$ will be disposed of at site $\mathrm{o}$ at time period $\mathrm{t}, \mathrm{0}$; otherwise

wst $_{k t} \quad$ Volume of water from treatment process $k$ to storage at time period $t$

$\mathrm{X}_{\mathrm{mkt}} \quad$ Quality type $\mathrm{m}$ entering treatment process $\mathrm{k}$ at time period $\mathrm{t}$

ast $_{n t} \quad$ Volume of water to storage after going through harvesting type $n$ at time period $t$

$\mathrm{w}_{\mathrm{mnt}} \quad$ Quality type $\mathrm{m}$ going through harvesting option $\mathrm{n}$ at time period $\mathrm{t}$

3 mit Quality type $m$ of water type i at time period $t$

$B_{\mathrm{mt}} \quad$ Quality type $\mathrm{m}$ of water of total water stored at time period $\mathrm{t}$

sta $_{j t} \quad$ Volume of water from storage to cultivation system $j$ at time period $t$

$\mathrm{wd}_{\mathrm{kot}} \quad$ Volume of water from treatment process $\mathrm{k}$ to disposal site $\mathrm{o}$ at time period $\mathrm{t}$

$\mathrm{C}_{\mathrm{jnt}} \quad$ Volume of water from cultivation type $\mathrm{j}$ to harvesting type $\mathrm{n}$ at time period $\mathrm{t}$

$\mathrm{fw}_{\mathrm{t}} \quad$ Volume of freshwater to be used at time period $t$

$\mathrm{Y}_{\text {not }}$ Binary, 1; water coming from harvesting type $\mathrm{n}$ will be disposed at site $\mathrm{o}$ at time period $\mathrm{t}, 0$; otherwise

$\mathrm{wd}_{\text {not }} \quad$ Volume of water that went through harvesting type $\mathrm{n}$ to disposal site $\mathrm{o}$ at time period $\mathrm{t}$

$\varepsilon_{\mathrm{m}} \quad$ Quality type $\mathrm{m}$ of freshwater to be used at time period $\mathrm{t}$

$\partial_{\mathrm{mjt}} \quad$ Quality type $\mathrm{m}$ of entering water in cultivation system $\mathrm{j}$ at time period $\mathrm{t}$

$\mathrm{bm}_{\mathrm{sjt}} \quad$ Amount of sludge from stabilization process $\mathrm{s}$ to cultivation system $\mathrm{j}$ at time period $\mathrm{t}$

$P_{\mathrm{mst}} \quad$ Quality type $\mathrm{m}$ of sludge after going through stabilization process $\mathrm{s}$ at time period $\mathrm{t}$

cynet Amount of algae cells from harvesting type $n$ to conversion process e at time period $t$

$\mathrm{ra}_{\mathrm{nt}}$ Amount of algae cells from harvesting type $\mathrm{n}$ to be sold in the market at time period $\mathrm{t}$

algnat Amount of algae cells from harvesting type $\mathrm{n}$ to undergo advanced treatment process a at time period $t$

$\operatorname{alg}_{\text {nst }} \quad$ Amount of algae cells from harvesting type $\mathrm{n}$ to undergo stabilization process $\mathrm{s}$ at time period $\mathrm{t}$

$\mathrm{BE}_{\mathrm{ebtd}}$ Amount of bioproducts $\mathrm{b}$ produced through conversion process e to become $\mathrm{d}$ at time period $\mathrm{t}$

$\mathrm{SS}_{\mathrm{st}} \quad$ Amount of sludge to undergo stabilization process $\mathrm{s}$ at time period $\mathrm{t}$

$\mathrm{SS}_{\mathrm{at}} \quad$ Amount of sludge to undergo advanced treatment process a at time period $\mathrm{t}$

$\mathrm{Q}_{\mathrm{mt}} \quad$ Quality type $\mathrm{m}$ of sludge produced at time period $\mathrm{t}$

$\mathrm{ds}_{\mathrm{st}} \quad$ Amount of sludge from stabilization process $\mathrm{s}$ to be disposed of at time period $\mathrm{t}$

$\mathrm{Ym}_{\mathrm{st}} \quad$ Binary, 1; if microalgae will be mixed with sludge during stabilization process $\mathrm{s}$ at time period $\mathrm{t}$

$P_{\text {mat }} \quad$ Quality type $m$ of sludge after going through advanced treatment process a at time period $t$

$\mathrm{Ym}_{\mathrm{at}} \quad$ Binary, 1; if microalgae will be mixed with sludge at advanced treatment process a at time period $\mathrm{t}, 0$; otherwise

$\mathrm{y}_{\text {slt }} \quad$ Binary, 1 ; if sludge from stabilization process $\mathrm{s}$ will be disposed of at disposal site 1 at time period $\mathrm{t}, 0$; otherwise

Binary, 1; if sludge from advanced treatment a will be disposed of at disposal site 1 at time period t, 0 ;

yalt otherwise

$\mathrm{BE}_{\mathrm{abtd}}$ Amount of bioproducts $\mathrm{b}$ produced through advanced treatment $\mathrm{a}$ to become $\mathrm{d}$ at time period $\mathrm{t}$

$\mathrm{BE}_{\mathrm{sbtd}}$ Amount of bioproducts $\mathrm{b}$ produced through stabilization process $\mathrm{s}$ to become $\mathrm{d}$ at time period $\mathrm{t}$

$\mathrm{sd}_{\mathrm{alt}} \quad$ Volume of sludge that went through advanced treatment process a to disposal site 1 at time period $\mathrm{t}$

$\mathrm{sd}_{\mathrm{slt}} \quad$ Volume of sludge that went through stabilization process $\mathrm{s}$ to disposal site 1 at time period $\mathrm{t}$ 
Table 1. Cont.

\begin{tabular}{|c|c|}
\hline \multicolumn{2}{|r|}{ Indices } \\
\hline \multicolumn{2}{|r|}{ Parameters } \\
\hline dem $_{\text {it }}$ & Demand of wastewater type $i$ to be treated at time period $t$ \\
\hline $\operatorname{cap}_{\mathrm{k}}$ & Capacity of water on treatment process $\mathrm{k}$ \\
\hline $\operatorname{tr}_{\mathrm{mj}}$ & Treatment rate of water going to cultivation system $\mathrm{j}$ for quality type $\mathrm{m}$ \\
\hline $\mathrm{acr}_{\mathrm{mjn}}$ & $\begin{array}{l}\text { Amount of algae cells produced from cultivation system } j \text { to harvesting option } n \text { for quality type } \\
\mathrm{m}\end{array}$ \\
\hline $\mathrm{er}_{\mathrm{emb}}$ & Bioenergy product $\mathrm{b}$ production rate for biomass in conversion process e for quality type $\mathrm{m}$ \\
\hline vth & Volume reduction rate for sludge entering the thickening process \\
\hline $\mathrm{sr}_{\mathrm{k}}$ & Sludge quantity production rate for water going through treatment process $\mathrm{k}$ \\
\hline $\mathrm{er}_{\mathrm{abm}}$ & $\begin{array}{l}\text { Bioenergy product } b \text { production rate for biomass in advanced treatment process a for quality } \\
\text { type } \mathrm{m}\end{array}$ \\
\hline$q i_{s m}$ & Sludge treatment rate for stabilization process $\mathrm{s}$ for quality type $\mathrm{m}$ \\
\hline $\mathrm{er}_{\mathrm{sbm}}$ & Bioenergy product $b$ production rate for biomass in stabilization process $\mathrm{s}$ for quality type $\mathrm{m}$ \\
\hline $\operatorname{cer}_{\mathrm{abm}}$ & $\begin{array}{l}\text { Bioenergy product } b \text { production rate for combined sludge and algae biomass in advanced } \\
\text { treatment process a for quality type } \mathrm{m}\end{array}$ \\
\hline $\operatorname{cer}_{\mathrm{sbm}}$ & $\begin{array}{l}\text { Bioenergy product b production rate for combined sludge and algae biomass in stabilization } \\
\text { process } \mathrm{s} \text { for quality type } \mathrm{m}\end{array}$ \\
\hline $\mathrm{vr}_{\mathrm{a}}$ & Volume reduction rate for sludge entering advanced treatment process a \\
\hline vde & Volume reduction rate for sludge entering the dewatering process \\
\hline $\mathrm{D}_{\mathrm{ml}}$ & Requirement on sludge quality $\mathrm{m}$ in output site 1 \\
\hline $\mathrm{R}_{\mathrm{mo}}$ & Requirement on water quality $\mathrm{m}$ in output site $\mathrm{o}$ \\
\hline$q i_{a m}$ & Sludge treatment rate for advanced treatment process a for quality type $\mathrm{m}$ \\
\hline $\mathrm{N}_{\mathrm{k}}$ & Rate of water lost after going through process $\mathrm{k}$ \\
\hline $\mathrm{N}_{\mathrm{j}}$ & Rate of water lost after going through cultivation system $\mathrm{j}$ \\
\hline $\operatorname{tr}_{\mathrm{mk}}$ & Treatment rate of water going to treatment process $\mathrm{k}$ for quality type $\mathrm{m}$ \\
\hline$A_{\text {mit }}$ & Water quality type $\mathrm{m}$ for water input $\mathrm{i}$ entering the system at time $\mathrm{t}$ \\
\hline $\mathrm{M}$ & A very large number \\
\hline $\operatorname{cap}_{j}$ & Capacity of water for cultivation system $\mathrm{j}$ \\
\hline caps $_{\text {s }}$ & Capacity of sludge for stabilization process $\mathrm{s}$ \\
\hline capa & Capacity of sludge for advanced treatment a \\
\hline $\mathrm{vr}_{\mathrm{S}}$ & Volume reduction rate for sludge entering stabilization process s \\
\hline $\operatorname{tr}_{\mathrm{mn}}$ & Treatment rate of water going through harvesting option $\mathrm{n}$ for quality type $\mathrm{m}$ \\
\hline $\mathrm{vc}_{\mathrm{k}}$ & Processing cost for water entering treatment process $\mathrm{k}$ \\
\hline $\mathrm{vc}_{\mathrm{j}}$ & Processing cost for water entering cultivation system $\mathrm{j}$ \\
\hline $\mathrm{vc}_{\mathrm{n}}$ & Processing cost for water to be processed in harvesting option $n$ \\
\hline $\mathrm{vc}_{\mathrm{e}}$ & Processing cost for algae to be processed at conversion process e \\
\hline $\mathrm{vc}_{\mathrm{S}}$ & Processing cost for sludge/biomass to enter stabilization process s \\
\hline $\mathrm{vc}_{\mathrm{a}}$ & Processing cost for sludge/biomass to enter advanced treatment process a \\
\hline hc & Holding cost for storage \\
\hline vct & Processing cost for sludge to enter the thickening process \\
\hline vcd & Processing cost for sludge to enter the dewatering process \\
\hline $\mathrm{dc}_{\mathrm{o}}$ & Disposal cost for water to be discharged at output site o \\
\hline $\mathrm{sdc}_{1}$ & Disposal cost for sludge to be discharge at output site 1 \\
\hline$m p_{t}$ & Market price for algae at time period $t$ \\
\hline mpbtd & Profit from bioproduct $\mathrm{b}$ becoming $\mathrm{d}$ at time period $\mathrm{t}$ \\
\hline $\mathrm{em}_{\mathrm{j}}$ & Carbon emissions per mass produced in cultivation system $\mathrm{j}$ \\
\hline $\mathrm{em}_{\mathrm{n}}$ & Carbon emissions per mass produced in harvesting option $n$ \\
\hline $\mathrm{em}_{\mathrm{s}}$ & Carbon emissions per mass produced in stabilization process $\mathrm{s}$ \\
\hline $\mathrm{em}_{\mathrm{a}}$ & Carbon emissions per mass produced in advanced treatment process a \\
\hline $\mathrm{em}_{\mathrm{o}}$ & Carbon emissions per mass produced in disposing water at disposal site o \\
\hline sem $_{1}$ & Carbon emissions per mass produced in disposing sludge at disposal site 1 \\
\hline ghs $_{\text {btd }}$ & Greenhouse emission savings for bioproduct $b$ to become $d$ at time period $t$ \\
\hline
\end{tabular}




\subsection{Constraints}

Equation (1) displays the total demand of wastewater to be treated at a certain period. These could be accommodated by either the WTS, MBP, or to be stored to be treated on the following period. This is shown to be equivalent to the wastewater demand for the given period.

$$
\sum_{\mathrm{k}} \mathrm{U}_{\mathrm{ikt}}+\sum_{\mathrm{j}} \mathrm{V}_{\mathrm{ijt}}+\mathrm{se}_{\mathrm{it}}=\operatorname{dem}_{\mathrm{it}} \forall \mathrm{i}, \mathrm{t}
$$

The following set of equations are concerned with the water being stored during a particular period. Equation (2) shows that the volume of water in the inventory consists of the treated water in the wastewater treatment process, water after going microalgae harvesting, and water planned to be treated for the succeeding periods. The stored water would then be treated in the WTS or used as a cultivation medium for the following period. Ang et al. [16] utilized the method of calculating the total quality of water through the weighted average of the input quality with respect to its volume. This is used to calculate the quality of water stored at the current period and is displayed in Equation (3).

$$
\begin{gathered}
\sum_{\mathrm{k}} \mathrm{wst}_{\mathrm{kt}}+\sum_{\mathrm{n}} \text { ast }_{\mathrm{nt}}+\sum_{\mathrm{I}} \mathrm{se}_{\mathrm{it}}=\sum_{\mathrm{k}} \mathrm{stw}_{\mathrm{kt}}+\sum_{\mathrm{j}} \mathrm{sta}_{\mathrm{jt}} \forall \mathrm{t} \\
\sum_{\mathrm{k}} \mathrm{X}_{\mathrm{mkt}}\left(\mathrm{wst}_{\mathrm{kt}}\right)+\sum_{\mathrm{n}} \mathrm{w}_{\mathrm{mnt}}\left(\mathrm{ast}_{\mathrm{nt}}\right)+\sum_{\mathrm{I}} \mathrm{se}_{\mathrm{it}}(\mathrm{d})=\beta_{\mathrm{mt}}\left(\sum_{\mathrm{k}} \mathrm{wst}_{\mathrm{kt}}+\sum_{\mathrm{n}} \mathrm{ast}_{\mathrm{nt}}+\sum_{\mathrm{I}} \mathrm{se}_{\mathrm{it}}\right) \forall \mathrm{m}, \mathrm{t}
\end{gathered}
$$

The following sets of equations are concerned with the processes done in the wastewater treatment facility. Equation (4) displays the volume quantity of the water entity entering and exiting each treatment process that would be utilized. The constraint provides assurance that wastewater will not return to previous treatment processes. It would move to succeeding treatments in WTS if necessary, be disposed of, or moved to storage. Water coming from the algae bioenergy park $\left(\mathrm{stw}_{\mathrm{kt}}\right)$ can be treated by the wastewater treatment facility in the following period. A percentage of water input $\left(\mathrm{N}_{\mathrm{k}}\right)$ would be lost due to evaporation and other factors and would therefore be considered for each treatment process. The quality of water entering the treatment process is calculated in Equation (5). This will be equal to the total weighted average of the water entering the process. Equation (6) makes sure that the effluent quality requirements are met before letting water be discharged from the facility.

$$
\begin{aligned}
\left(1-\mathrm{N}_{\mathrm{k}}\right)\left[\sum_{\mathrm{i}} \mathrm{U}_{\mathrm{ikt}}+\sum_{\mathrm{k}^{\prime}} \mathrm{P}_{\mathrm{k}^{\prime} \mathrm{kt}}+\operatorname{stw}_{\mathrm{k}(\mathrm{t}-1)}\right] & =\sum_{\mathrm{k}^{\prime \prime}} \mathrm{P}_{\mathrm{kk} \mathrm{k}^{\prime \prime} \mathrm{t}}+\mathrm{Y}_{\mathrm{kot}}\left(\mathrm{wd}_{\mathrm{kot}}\right)+\mathrm{wst}_{\mathrm{kt}} \forall \mathrm{k}, \mathrm{t} \\
\mathrm{k}^{\prime} & \leq \mathrm{k} \\
\mathrm{k}^{\prime \prime} & \geq \mathrm{k}
\end{aligned}
$$

Equations (7)-(14) are concerned with the processes that are done at the microalgae bioenergy park. The mass balance of the volume of water to enter the cultivation systems available are shown in Equation (7). $\left(\mathrm{N}_{\mathrm{j}}\right)$ serves as the amount of water lost after the cultivation process. Freshwater is allowed to be combined with the entering wastewater if necessary to improve water quality and reduce the chances of microalgae contamination. The quality of water entering each cultivation system is shown in Equation (8).

$$
\begin{gathered}
\left(1-\mathrm{N}_{\mathrm{j}}\right)\left[\sum_{\mathrm{I}} \mathrm{v}_{\mathrm{ijjt}}+\mathrm{sta}_{\mathrm{j}(\mathrm{t}-1)}+\mathrm{fw}_{\mathrm{t}}\right]=\sum_{\mathrm{n}} \mathrm{C}_{\mathrm{jnt}} \forall \mathrm{j}, \mathrm{t} \\
\sum_{\mathrm{i}} \mathrm{V}_{\mathrm{ijt}}\left(\mathrm{A}_{\mathrm{mit}}\right)+\mathrm{fw}_{\mathrm{t}}\left(\varepsilon_{\mathrm{m}}\right)+\operatorname{sta}_{\mathrm{j}(\mathrm{t}-1)}\left(\beta_{\mathrm{m}(\mathrm{t}-1)}\right)=\partial_{\mathrm{mjt}}\left(\sum_{\mathrm{i}} \mathrm{V}_{\mathrm{ijjt}}+\mathrm{fw}_{\mathrm{t}}+\mathrm{sta}_{\mathrm{j}(\mathrm{t}-1)}\right) \forall \mathrm{j}, \mathrm{m}, \mathrm{t}
\end{gathered}
$$

The volume flow of water to undergo each harvesting option and quality after each process are shown in Equations (9) and (10), respectively. Water used after the harvesting process would either be disposed of or be stored for additional treatment in the succeeding period. Equation (11) ensures that water quality can meet the specified requirements before being discharged from the facility. The microalgae cells produced after going through cultivation and harvesting steps can either be sold, 
processed further to be converted into a bioproduct, or be co-processed with sludge in the next period, as shown in Equation (12). Equation (13) shows the total amount of algae to be co-processed with sludge in the stabilization and advanced treatment process for the succeeding period. Equation (14) shows the conversion of microalgae cells into bioproducts. The volatile solid content of biomass is associated with the bioenergy production [38]

$$
\begin{aligned}
& \sum_{\mathrm{j}} C_{\mathrm{jnt}}=\mathrm{Y}_{\text {not }}\left(\mathrm{wd}_{\mathrm{not}}\right)+\operatorname{ast}_{\mathrm{nt}} \forall \mathrm{n}, \mathrm{t} \\
& \sum_{\mathrm{j}} \mathrm{C}_{\mathrm{jnt}}\left[\varepsilon_{\mathrm{mjt}}\left(1-\operatorname{tr}_{\mathrm{mj}}\right)\right]=\mathrm{w}_{\mathrm{mnt}}\left(\sum_{\mathrm{j}} \mathrm{C}_{\mathrm{jnt}}\right) \forall \mathrm{m}, \mathrm{n}, \mathrm{t} \\
& \mathrm{w}_{\mathrm{mnt}}\left(1-\operatorname{tr}_{\mathrm{mn}}\right) \leq \mathrm{R}_{\mathrm{mo}}+\mathrm{M}\left(1-\mathrm{Y}_{\text {not }}\right) \forall \mathrm{m}, \mathrm{n}, \mathrm{o}, \mathrm{t} \\
& {\left[\sum_{\mathrm{j}} \mathrm{C}_{\mathrm{jnt}}\left(\sum_{\mathrm{m}} \varepsilon_{\mathrm{mjt}}\right)+\sum_{\mathrm{s}} \sum_{\mathrm{j}} \mathrm{bm}_{\mathrm{sj}(\mathrm{t}-1)}\left(\mathrm{P}_{\mathrm{mst}}\right)\right] \mathrm{acr}_{\mathrm{mjn}}=\sum_{\mathrm{e}} \mathrm{cy}_{\mathrm{net}}+\mathrm{ra}_{\mathrm{nt}}+\operatorname{alg}_{\mathrm{nt}} \forall \mathrm{n}, \mathrm{t}} \\
& \sum_{\mathrm{n}} \operatorname{alg}_{\mathrm{nt}}=\sum_{\mathrm{s}} \sum_{\mathrm{n}} \operatorname{alg}_{\mathrm{nst}}+\sum_{\mathrm{a}} \sum_{\mathrm{n}} \operatorname{alg}_{\mathrm{nat}} \forall \mathrm{t} \\
& \sum_{\mathrm{b}} \mathrm{er}_{\mathrm{emb}}\left[\sum_{\mathrm{n}} \mathrm{w}_{\mathrm{mnt}}\left(\mathrm{cy}_{\text {net }}\right)\right]=\sum_{\mathrm{d}} \sum_{\mathrm{b}} \mathrm{BE}_{\mathrm{ebtd}}\left(\mathrm{cy}_{\text {net }}\right) \forall \mathrm{e}, \mathrm{t} ; \mathrm{m}=\mathrm{VS} \text {. }
\end{aligned}
$$

The equations below are concerned with the handling of sludge produced in the system. Equation (15) shows the total amount of sludge produced in the current period that would either go through stabilization or advanced treatment process for treatment. Sludge would undergo the thickening process (vth) first, which would reduce the total volume. Sludge production is dependent on the treatment process of wastewater as well as its quality, particularly the biochemical oxygen demand of the water [39]. Equation (16) tackles the quality of the total sludge produced in the current period.

$$
\begin{gathered}
\text { vth }\left(\sum_{\mathrm{k}}\left[\mathrm{sr}_{\mathrm{k}}\left(\mathrm{X}_{\mathrm{mkt}}\right)\right]\left[\sum_{\mathrm{i}} \sum_{\mathrm{k}} \mathrm{U}_{\mathrm{ikt}}+\sum_{\mathrm{k}^{\prime}} \sum_{\mathrm{k}} \mathrm{P}_{\mathrm{k}^{\prime} \mathrm{kt}}+\sum_{\mathrm{k}} \operatorname{stw}_{\mathrm{k}(\mathrm{t}-1)}\right]\right)=\sum_{\mathrm{s}} \mathrm{SS}_{\mathrm{st}}+\sum_{\mathrm{a}} \mathrm{SS}_{\mathrm{at}} \forall \mathrm{t} ; \mathrm{m}=\mathrm{BOD} \\
\sum_{\mathrm{k}} \mathrm{X}_{\mathrm{mkt}}\left[\sum_{\mathrm{i}} \mathrm{U}_{\mathrm{ikt}}+\sum_{\mathrm{k}^{\prime}} \mathrm{P}_{\mathrm{k}^{\prime} \mathrm{kt}}+\operatorname{stw}_{\mathrm{k}(\mathrm{t}-1)}\right]=\mathrm{Q}_{\mathrm{mt}}\left(\sum_{\mathrm{k}}\left[\sum_{\mathrm{i}} \mathrm{U}_{\mathrm{ikt}}+\sum_{\mathrm{k}^{\prime}} \mathrm{P}_{\mathrm{k}^{\prime} \mathrm{kt}}+\operatorname{stw}_{\mathrm{k}(\mathrm{t}-1)}\right]\right) \forall \mathrm{m}, \mathrm{t}
\end{gathered}
$$

Treatment of sludge and added algae after going through the stabilization process is tackled in Equation (17). Algae produced in the previous period can be added in the stabilization process to enhance the sludge quality, which would ultimately increase the bioenergy production. Stabilized sludge can either be disposed of afterwards or transferred to a microalgae bioenergy park to be added in the cultivation system, as shown in Equation (18). After going through a stabilization process, the sludge would then undergo through the dewatering step, which would further reduce the amount of sludge disposed of. Equation (19) displays the total amount of sludge that came from the stabilization process to be disposed of at a particular period and Equation (20) makes sure that the quality requirement is met before disposal.

$$
\begin{gathered}
\mathrm{qi}_{\mathrm{sm}}\left[\left(\mathrm{SS}_{\mathrm{st}}\right) \mathrm{Q}_{\mathrm{mt}}+\sum_{\mathrm{n}} \operatorname{alg}_{\mathrm{ns}(\mathrm{t}-1)}\left(\mathrm{w}_{\mathrm{mn}(\mathrm{t}-1)}\right)\right]=\mathrm{P}_{\mathrm{mst}}\left[\left(\mathrm{SS}_{\mathrm{st}}\right)+\sum_{\mathrm{n}} \operatorname{alg} \mathrm{ns}_{\mathrm{n}(\mathrm{t}-1)}\right] \forall \mathrm{m}, \mathrm{s}, \mathrm{t} \\
\sum_{\mathrm{s}} \mathrm{vr}_{\mathrm{s}}\left(\mathrm{SS}_{\mathrm{st}}\right)=\left(\sum_{\mathrm{s}} \sum_{\mathrm{j}} \mathrm{bm}_{\mathrm{sjt}}+\sum_{\mathrm{s}} \mathrm{ds}_{\mathrm{st}}\right) \forall \mathrm{t} \\
\operatorname{vde}\left(\mathrm{ds}_{\mathrm{st}}+\mathrm{vr}_{\mathrm{s}}\left(\operatorname{alg} \mathrm{als}_{\mathrm{n}(\mathrm{t}-1)}\right)\right)=\sum_{\mathrm{l}} \mathrm{Y}_{\mathrm{slt}}\left(\mathrm{sd}_{\mathrm{slt}}\right) \forall \mathrm{s}, \mathrm{t} \\
\mathrm{P}_{\mathrm{mst}} \leq \mathrm{D}_{\mathrm{ml}}+\mathrm{M}\left(1-\mathrm{Y}_{\mathrm{slt}}\right) \forall \mathrm{m}, \mathrm{l}, \mathrm{s}, \mathrm{t}
\end{gathered}
$$

Equation (21) shows the quality improvement of sludge and microalgae added after going through an advanced treatment process. Unlike the stabilization step, sludge will first go through the dewatering step before the advanced treatment to reduce moisture content, which will consequently reduce the total volume processed. The total amount of sludge disposed after going through an advanced treatment process and meeting quality requirements for disposal are shown in Equations (22) and (23), respectively.

$$
\mathrm{qi}_{\mathrm{am}}\left[(\mathrm{vde})\left(\mathrm{SS}_{\mathrm{at}}\right) \mathrm{Q}_{\mathrm{mt}}+\sum_{\mathrm{n}} \operatorname{alg}_{\mathrm{na}(\mathrm{t}-1)}\left(\mathrm{w}_{\mathrm{mn}(\mathrm{t}-1)}\right)\right]=\mathrm{P}_{\mathrm{mat}}\left[\left(\mathrm{SS}_{\mathrm{at}}\right)(\mathrm{vde})+\sum_{\mathrm{n}} \operatorname{alg}_{\mathrm{na}(\mathrm{t}-1)}\right] \forall \mathrm{m}, \mathrm{a}, \mathrm{t}
$$




$$
\begin{gathered}
\operatorname{vde}\left(\mathrm{SS}_{\mathrm{at}}+(\operatorname{alg} \mathrm{ana}(\mathrm{t}-1))\right)=\sum_{1} \mathrm{Y}_{\mathrm{alt}}\left(\mathrm{sd}_{\mathrm{alt}}\right) \forall \mathrm{a}, \mathrm{t} \\
\mathrm{P}_{\text {mat }} \leq \mathrm{D}_{\mathrm{ml}}+\mathrm{M}\left(1-\mathrm{Y}_{\text {alt }}\right) \forall \mathrm{m}, \mathrm{l}, \mathrm{a}, \mathrm{t}
\end{gathered}
$$

Energy production for the stabilization process is shown in Equation (24), while Equation (25) is concerned with the energy production for the advanced treatment process. Different energy rates are considered with sludge processed alone and when additional algae biomass is used. Similar to during energy conversion for algal biomass, the volatile solids contents of the sludge are considered in these sets of equations. Equations (26) and (27) activate the combined energy rate for biomass when microalgae is added for stabilization and advanced treatment processes, respectively.

$$
\begin{gathered}
\operatorname{er}_{\mathrm{sbm}}\left(1-\mathrm{Ym}_{\mathrm{st}}\right)+\operatorname{cer}_{\mathrm{sbm}}\left(\mathrm{Ym}_{\mathrm{st}}\right)\left[S S_{\mathrm{st}}\left(\mathrm{Qmt}_{\mathrm{mt}}\right)+\sum_{\mathrm{n}} \operatorname{alg} \mathrm{gns}_{\mathrm{n}(\mathrm{t}-1)} \mathrm{w}_{\mathrm{mn}(\mathrm{t}-1)}\right]=\sum_{\mathrm{d}} \mathrm{BE}_{\mathrm{sbtd}} \forall \mathrm{s}, \mathrm{t}, \mathrm{b} ; \mathrm{m}=\mathrm{VS} \\
\operatorname{er}_{\mathrm{abm}}\left(1-\mathrm{Ym}_{\mathrm{at}}\right)+\operatorname{cer}_{\mathrm{abm}}\left(\mathrm{Ym}_{\mathrm{at}}\right)\left[\mathrm{SS}_{\mathrm{at}}\left(\mathrm{Q}_{\mathrm{mt}}\right)+\sum_{\mathrm{n}} \operatorname{alg} \mathrm{na(t-1)} \mathrm{w}_{\mathrm{mn}(\mathrm{t}-1)}\right]=\sum_{\mathrm{d}} \mathrm{BE}_{\mathrm{abtd}} \forall \mathrm{a}, \mathrm{t}, \mathrm{b} ; \mathrm{m}=\mathrm{VS} \\
\sum_{\mathrm{n}} \operatorname{alg}_{\mathrm{ns}(\mathrm{t}-1)} \leq \mathrm{M}\left(\mathrm{Ym}_{\mathrm{st}}\right) \forall \mathrm{s}, \mathrm{t} \\
\sum_{\mathrm{n}} \operatorname{alg}_{\mathrm{na}(\mathrm{t}-1)} \leq \mathrm{M}\left(\mathrm{Ym}_{\mathrm{at}}\right) \forall \mathrm{a}, \mathrm{t}
\end{gathered}
$$

Equation (28) limits the amount of water entering the treatment process in the WTS. Each cultivation system in the ABP also has a specific capacity that it can handle for a particular period, as presented in Equation (29). The capacity of sludge and algae biomass to enter stabilization and advanced treatment processes is shown in Equations (30) and (31), respectively.

$$
\begin{gathered}
\sum_{\mathrm{i}} \mathrm{U}_{\mathrm{ikt}}+\sum_{\mathrm{k}^{\prime}} \mathrm{P}_{\mathrm{k}^{\prime} \mathrm{kt}}+\mathrm{stw}_{\mathrm{k}(\mathrm{t}-1)} \leq \mathrm{cap}_{\mathrm{k}} \forall \mathrm{k}, \mathrm{t} \\
\sum_{\mathrm{i}} \mathrm{V}_{\mathrm{ijt}}+\mathrm{sta}_{\mathrm{j}(\mathrm{t}-1)}+\mathrm{fw}_{\mathrm{t}} \leq \mathrm{cap}_{\mathrm{j}} \forall \mathrm{j}, \mathrm{t} \\
\mathrm{SS}_{\mathrm{st}}+\operatorname{alg}_{\mathrm{s}(\mathrm{t}-1)} \leq \operatorname{cap}_{\mathrm{s}} \forall \mathrm{s}, \mathrm{t} \\
\mathrm{SS}_{\mathrm{at}}+\operatorname{alg}_{\mathrm{a}(\mathrm{t}-1)} \leq \operatorname{cap}_{\mathrm{a}} \forall \mathrm{a}, \mathrm{t}
\end{gathered}
$$

\subsection{Objective Function}

The model has been developed to maximize the performance of both cost and environmental objectives. A balance between the two objectives is achieved by maximizing the least desirable value to avoid the optimization of one objective and sacrificing the other as seen in Equation (32). This methodology has been utilized in multiple studies in striking a balance between two objectives, particularly cost and environmental impact $[25,26]$ As such, the overall efficiency value of the system is the lower efficiency value between the cost and the environmental impact. The efficiency values are calculated by dividing the value of the achieved improvement (difference between worst and actual values) to the potential improvement (difference between worst and best values). These values correspond to the results of the bi-objective optimization being compared to its single objective counterparts. The best values ( Cost $_{\text {best }}$ and $E_{\text {best }}$ ) for cost and environmental impact are obtained through the application of single objective optimization for the respective objective. The worst values (Cost ${ }_{\text {worst }}$ and $\left.\mathrm{Env}_{\text {worst }}\right)$, on the other hand, are obtained by treating one particular objective as a system variable and optimizing the other conflicting objective. In the case of Cost worst $_{\text {, }}$ it is the cost value when a single-objective optimization is set for environmental impact and for Env $_{\text {worst, }}$ it is set for optimizing cost.

$$
\operatorname{Max} Z=\min \left[\left\{\left(\operatorname{Cost}_{\text {worst }}-\text { Cost }\right) /\left(\operatorname{Cost}_{\text {worst }}-\operatorname{Cost}_{\text {best }}\right)\right\},\left\{\left(\operatorname{Env}_{\text {worst }}-\text { Env }\right) /\left(\operatorname{Env}_{\text {worst }}-\text { Env }_{\text {best }}\right)\right\}\right]
$$

\subsubsection{Economic Objective}

The total economic objective function shown in Equation (33) includes the operating cost for using different available processes for water, sludge, and microalgae, holding cost for the total amount 
of water held in storage, the cost of freshwater entering the cultivation system, the disposal cost of water and sludge discharged from the facilities, and the deduction of cost from potential savings from the biomass produced. The operating cost for each process on the wastewater treatment facility $\left(\mathrm{vc}_{\mathrm{k}}\right)$ is considered on a per liter basis and is incurred depending on the amount of water to be treated. The cost of holding water to be treated in the succeeding period is defined as (hc). The operating costs for microalgae cultivation and harvesting are also calculated on a per liter basis and are defined as $\left(\mathrm{vc}_{\mathrm{j}}\right)$ and $\left(\mathrm{v \textrm {C } _ { h }}\right)$, respectively. Using freshwater for growing microalgae would incur additional costs (cc) if this medium is added. Processing of microalgae biomass for biofuel production would incur additional operating costs $\left(\mathrm{vc}_{\mathrm{e}}\right)$. The sludge would be treated in the sludge bioenergy park through either stabilization or advanced treatment options, which the costs are represented as $\left(\mathrm{vc}_{\mathrm{s}}\right)$ and $\left(\mathrm{vc}_{\mathrm{a}}\right)$, respectively. Finally, the disposal cost of water $\left(\mathrm{dc}_{0}\right)$ and sludge $\left(\mathrm{sdc}_{1}\right)$ are considered depending on the amount released.

The bioproducts and raw microalgae may be sold in the market resulting in profits, while the bioproducts may be used as energy to run the facilities, which is tackled in Equation (34). The microalgae produced may be sold afterwards without further processing, which gives a profit of $\left(\mathrm{mp}_{\mathrm{t}}\right)$. The profit and utilization of the biodiesel produced by sludge and algae bioenergy parks are represented by $\left(m p_{b t d}\right)$. These are considered as savings and would lessen the total economic cost incurred by the system.

$$
\begin{aligned}
& \text { Cost }=\Sigma_{\mathrm{k}} \Sigma_{\mathrm{t}}\left[\Sigma_{\mathrm{I}} \mathrm{U}_{\mathrm{ikt}}+\sum_{\mathrm{k}^{\prime}} \mathrm{P}_{\mathrm{k}^{\prime} \mathrm{kt}}+\mathrm{stw}_{\mathrm{k}(\mathrm{t}-1)}\right]\left(\mathrm{vc}_{\mathrm{k}}\right)+\sum_{\mathrm{j}} \Sigma_{\mathrm{t}}\left(\sum_{\mathrm{n}} \mathrm{C}_{\mathrm{jnt}}+\sum_{\mathrm{s}} \mathrm{bm}_{\mathrm{sit}}\right)\left(\mathrm{vc}_{\mathrm{j}}\right)+\mathrm{fw}_{\mathrm{t}}(\mathrm{ccc})+\sum_{\mathrm{n}} \Sigma_{\mathrm{t}} \\
& \left(\Sigma_{\mathrm{j}} \mathrm{C}_{\mathrm{jnt}}\right)\left(\mathrm{vc}_{\mathrm{n}}\right)+\sum_{\mathrm{e}} \sum_{\mathrm{t}}\left(\sum_{\mathrm{n}} \mathrm{CY} \mathrm{Y}_{\mathrm{net}}+\mathrm{alg}_{\mathrm{et}}\right)\left(\mathrm{vc}_{\mathrm{e}}\right)+\sum_{\mathrm{t}}\left(\sum_{\mathrm{k}} \mathrm{stw}_{\mathrm{kt}}+\sum_{\mathrm{j}} \mathrm{stw}_{\mathrm{jt}}\right)(\mathrm{hc})+\sum_{\mathrm{s}} \sum_{\mathrm{t}}\left(\mathrm{SS}_{\mathrm{st}}\right)\left(\mathrm{vc}_{\mathrm{s}}\right)+ \\
& \Sigma_{\mathrm{a}} \sum_{\mathrm{t}}\left(\mathrm{SS}_{\mathrm{at}}\right)\left(\mathrm{vc}_{\mathrm{a}}\right)+\sum_{\mathrm{s}} \Sigma_{\mathrm{t}} \mathrm{alg}_{\mathrm{st}}\left(\mathrm{vc}_{\mathrm{s}}\right)+\sum_{\mathrm{a}} \sum_{\mathrm{t}} \operatorname{alg}_{\mathrm{at}}\left(\mathrm{vc}_{\mathrm{a}}\right)+\sum_{\mathrm{e}} \Sigma_{\mathrm{t}}\left(\mathrm{CY}_{\mathrm{net}}+\mathrm{alg}_{\mathrm{et}}\right)\left(\mathrm{vc}_{\mathrm{e}}\right)+\sum_{\mathrm{t}} \sum_{\mathrm{o}}\left(\sum_{\mathrm{k}} \mathrm{wd}_{\mathrm{kot}}+\right. \\
& \left.\sum_{\mathrm{n}} \mathrm{wd}_{\mathrm{not}}\right)\left(\mathrm{dc}_{\mathrm{o}}\right)+\sum_{\mathrm{l}} \sum_{\mathrm{t}}\left(\sum_{\mathrm{s}} \mathrm{sd}_{\mathrm{slt}}+\sum_{\mathrm{a}} \mathrm{sd}_{\mathrm{alt}}\right)\left(\mathrm{sdc}_{\mathrm{l}}\right)-\text { Savings } \\
& \text { Savings }=\sum_{\mathrm{t}} \mathrm{ra}_{\mathrm{t}}\left(\mathrm{mp}_{\mathrm{t}}\right)+\sum_{\mathrm{d}} \sum_{\mathrm{b}} \sum_{\mathrm{t}}\left(\sum_{\mathrm{e}} \mathrm{BE}_{\mathrm{ebtd}}+\sum_{\mathrm{a}} \mathrm{BE}_{\mathrm{abtd}}+\sum_{\mathrm{s}} \mathrm{BE}_{\mathrm{sbtd}}\right)\left(\mathrm{mp}_{\mathrm{btd}}\right)
\end{aligned}
$$

\subsubsection{Environmental Impact Objective}

Carbon emissions obtained from using the processes available in each of the facilities and the disposal of water and sludge are considered in the environmental impact shown in Equation (35). Carbon emissions in the wastewater treatment facility are calculated depending on the amount of water treated on each process $\left(\mathrm{em}_{\mathrm{k}}\right)$. Cultivation and harvesting processes would also incur emissions depending on the amount of water to be processed and are represented by $\left(\mathrm{em}_{\mathrm{j}}\right)$ and $\left(\mathrm{em}_{\mathrm{n}}\right)$, respectively. Carbon emissions in the conversion process of microalgae are calculated depending on the amount of biomass processed for each process $\left(\mathrm{em}_{\mathrm{e}}\right)$. Emissions from stabilization and advanced treatments of sludge are defined as $\left(\mathrm{em}_{\mathrm{s}}\right)$ and $\left(\mathrm{em}_{\mathrm{a}}\right)$, respectively. Lastly, disposal of the treated water and sludge would also add carbon emissions, which are represented as $\left(\mathrm{em}_{\mathrm{o}}\right)$ and $\left(\mathrm{sem}_{\mathrm{l}}\right)$, respectively.

The use of bioproducts for energy in running the facilities are considered as greenhouse emission savings shown in Equation (36). ( $\mathrm{ghs}_{\mathrm{btd}}$ ) represents the greenhouse emission reduction from the generation of bioenergy products, which will reduce the overall environmental impact caused by the system.

$$
\begin{gathered}
\text { Env }=\sum_{\mathrm{k}} \sum_{\mathrm{t}}\left(\sum_{\mathrm{I}} \mathrm{U}_{\mathrm{ikt}}+\sum_{\mathrm{k}^{\prime}} \mathrm{P}_{\mathrm{k}^{\prime} \mathrm{kt}}+\mathrm{stw}_{\mathrm{k}(\mathrm{t}-1)}\right)+\sum_{\mathrm{j}} \sum_{\mathrm{t}}\left(\left(\sum_{\mathrm{n}} \mathrm{C}_{\mathrm{jnt}}+\sum_{\mathrm{s}} \mathrm{bm}_{\mathrm{sj}}\right)\left(\mathrm{em}_{\mathrm{j}}\right)+\sum_{\mathrm{n}} \sum_{\mathrm{t}} \sum_{\mathrm{j}}\left(\mathrm{C}_{\mathrm{jnt}}\right)\left(\mathrm{em}_{\mathrm{n}}\right)+\right. \\
\sum_{\mathrm{s}} \sum_{\mathrm{t}}\left(\mathrm{SS}_{\mathrm{st}}+\mathrm{alg}_{\mathrm{st}}\right)\left(\mathrm{em}_{\mathrm{s}}\right)+\sum_{\mathrm{a}} \sum_{\mathrm{t}}\left(\mathrm{SS}_{\mathrm{at}}+\mathrm{alg}_{\mathrm{at}}\right)\left(\mathrm{em}_{\mathrm{a}}\right)+\sum_{\mathrm{o}} \sum_{\mathrm{t}}\left(\sum_{\mathrm{k}} \mathrm{wd}_{\mathrm{kot}}+\sum_{\mathrm{n}} \mathrm{wd}_{\mathrm{not}}\right)\left(\mathrm{em}_{\mathrm{o}}\right)+\sum_{\mathrm{l}} \Sigma_{\mathrm{t}} \\
\left(\sum_{\mathrm{s}} \mathrm{sd}_{\mathrm{slt}}+\sum_{\mathrm{a}} \mathrm{sd}_{\mathrm{alt}}\right)\left(\mathrm{sem}_{\mathrm{l}}\right)-\text { Greenhouse Emission Savings }
\end{gathered}
$$

$$
\text { Greenhouse Emission Savings }=\sum_{\mathrm{d}} \sum_{\mathrm{b}} \sum_{\mathrm{t}}\left[\sum_{\mathrm{e}} \mathrm{BE}_{\mathrm{ebtd}}+\sum_{\mathrm{a}} \mathrm{BE}_{\mathrm{abtd}}+\sum_{\mathrm{s}} \mathrm{BE}_{\mathrm{sbtd}}\right]\left(\mathrm{ghs}_{\mathrm{btd}}\right)
$$

\section{Model Validation}

The model has been implemented in MATLAB and solved using IBM CPLEX, with a solution time of $186.5 \mathrm{~min}$ on a Dell XPS 15 with a $2.8 \mathrm{GHz}$ Intel Core i5 processor and 8 GB $2133 \mathrm{MHz}$ LPDDR3 RAM. The case study considered four available wastewater treatment processes in the WTS, two cultivation 
systems, two harvesting options, two options for stabilization, and two advanced treatment processes. Four quality types were considered for the entering water and sludge and two disposal sites were included for both water and sludge treated in a span of two time periods. The parameter values used were based on various literature sources shown in the Appendix A. Table A1 shows the quality requirements for water and sludge discharge while the cell production rate after passing through the cultivation and harvesting processes are shown in Table A2. Tables A3 and A4 summarize the quality improvement rate of the processes for water and sludge, respectively. Energy production rate for the processes in the bioenergy parks are shown in Table A5. The cost and carbon emission parameters used in the model are summarized in Tables A6 and A7, respectively.

Running the model through individual optimization first would collect the worst possible outcome for the other objective, as shown in Table 2. In order to compute the model results for multi-objective function, the model maximized the efficiency of both costs and environmental impacts (also shown in Table 2), which resulted in an efficiency rate of $73.72 \%$. The individual optimizations have also proved that the tradeoffs considered need to be met by both objectives. The economic objective was able to choose technology and pathways that yield in higher biomass from closed systems and co-processing of microalgae and sludge.

Table 2. Objective Function of Baseline Scenario.

\begin{tabular}{ccc}
\hline Objective Function & Economic Cost (in Dollars) & Environmental Impact (in kg) \\
\hline Economic cost only & $25,555.36$ & $28,476.57$ \\
Environmental impact only & 265.33 & 217.63 \\
Dual optimization & $26,323.14$ & 230.17 \\
\hline
\end{tabular}

Based on the results obtained, all three of the individual facilities were utilized by the model to some extent as displayed in Figure 2. In the first period, the wastewater was treated using the algae bioenergy park by going through cultivation system 2 and harvesting option 2 . Since the treatment in the ABP is not sufficient for reaching effluent discharge requirements, further treatment needed to be done in the following period. Water was held in storage, which incurs a holding cost. It was then transferred to the WTS in the following period. This pathway implies the importance of the connection of the three separate systems in obtaining the optimal solution. As in this case, the MBP could still be used to treat the stored water; however, the model decided to transfer it to the WTS since only minimal treatment is required to achieve the effluent requirements. Simply using the MBP again to treat the stored water may only lead to unnecessary costs being incurred.

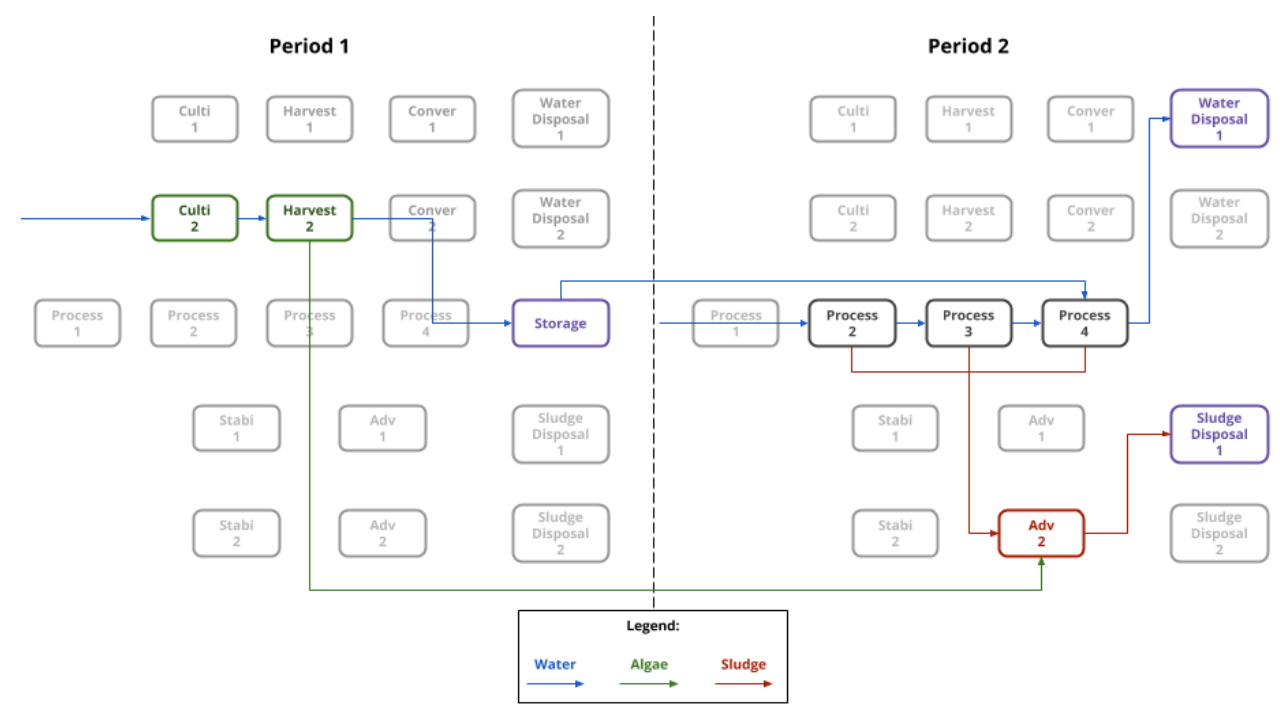

Figure 2. Treatment Network of Baseline Scenario. 
The wastewater demand in period 2 was treated solely using the processes available in the wastewater treatment plant before disposal. In treatment process 4 in the WTS, the wastewater was mixed with the stored wastewater from period 1 before receiving treatment and being sent to the disposal site. The sludge produced in this period was treated using advanced treatment option 2 before being disposed of. The algae produced in the first period was also transferred to the sludge plant for co-processing to further increase bioenergy production. Table 3 shows the summary of the decision pathways used in the scenario.

Table 3. Decision Variables of Baseline Scenario

\begin{tabular}{cccccc}
\hline \multicolumn{2}{c}{ Wastewater Treatment Plant } & \multicolumn{2}{c}{ Algae Bioenergy Park } & \multicolumn{2}{c}{ Sludge Bioenergy Park } \\
\hline $\begin{array}{c}\text { Amount of wastewater } \\
\text { treated (L) }\end{array}$ & 10,000 & $\begin{array}{c}\text { Amount of wastewater } \\
\text { treated (L) }\end{array}$ & 9000 & $\begin{array}{c}\text { Amount of sludge } \\
\text { produced (kg) }\end{array}$ & 1381.16 \\
\hline $\begin{array}{c}\text { Amount of wastewater } \\
\text { disposed (L) }\end{array}$ & $16,781.75$ & $\begin{array}{c}\text { Amount of wastewater } \\
\text { used as cultivation } \\
\text { medium (L) }\end{array}$ & 9000 & $\begin{array}{c}\text { Amount of sludge to be } \\
\text { used as biomass to algae } \\
\text { park (L) }\end{array}$ & 0 \\
\hline $\begin{array}{c}\text { Amount of sludge } \\
\text { disposed }(\mathrm{kg})\end{array}$ & 583.88 & $\begin{array}{c}\text { Amount of bioenergy } \\
\text { products produced }(\mathrm{kg})\end{array}$ & 171.72 & $\begin{array}{c}\text { Amount of bioenergy } \\
\text { products produced }(\mathrm{kg})\end{array}$ & 84.26 \\
\hline
\end{tabular}

In analyzing the importance of storage types in each major step or process of the system, all types were disregarded in the base model run. Restrictions in the transfer of water and biomass between plants were implemented in this scenario. With this setup, there are no water exchanges between the WTS and MBP, or biomass transfer between the MBP and SBP. As seen in Table 4, the economic and environmental objectives were relatively closer to each other; however, the efficiency of the model was only $50.03 \%$. In comparison to the previous model, it was able to find a more efficient balance between the two conflicting objectives.

Table 4. Objective Function without forms of Storage.

\begin{tabular}{ccc}
\hline Objective Function & Economic Cost (in Dollars) & Environmental Impact (in kg) \\
\hline Economic cost only & $23,383.78$ & $29,312.21$ \\
Environmental impact only & 388.88 & 337.11 \\
Dual optimization & $26,347.85$ & 362.99 \\
\hline
\end{tabular}

The decision pathways located in Figure 3 also display some differences as compared to the previous model with different types of storage available. Since transfer of effluent is not allowed, the algae bioenergy park was not utilized since the treatment that the facility provides does not reach the discharge requirements. While this removes the holding cost incurred for retaining water to be treated in the succeeding period, it also restricts the flexibility of processes that wastewater may go through in receiving full treatment. It also prohibits combining sludge and algae for increased biomass production. Hence, in the first period, processes 2 and 4 in the WTS were utilized to treat the wastewater before disposal. The sludge produced was treated using stabilization process 1 and disposed of afterwards. On the other hand, processes 2,3 , and 4 were necessary to treat the wastewater in period 2. The sludge produced was treated using the 2 nd advanced treatment option available and was disposed of afterwards. Table 5 shows the summary of the decision variables of the scenario without storage. 
Table 5. Decision Variables without Storage.

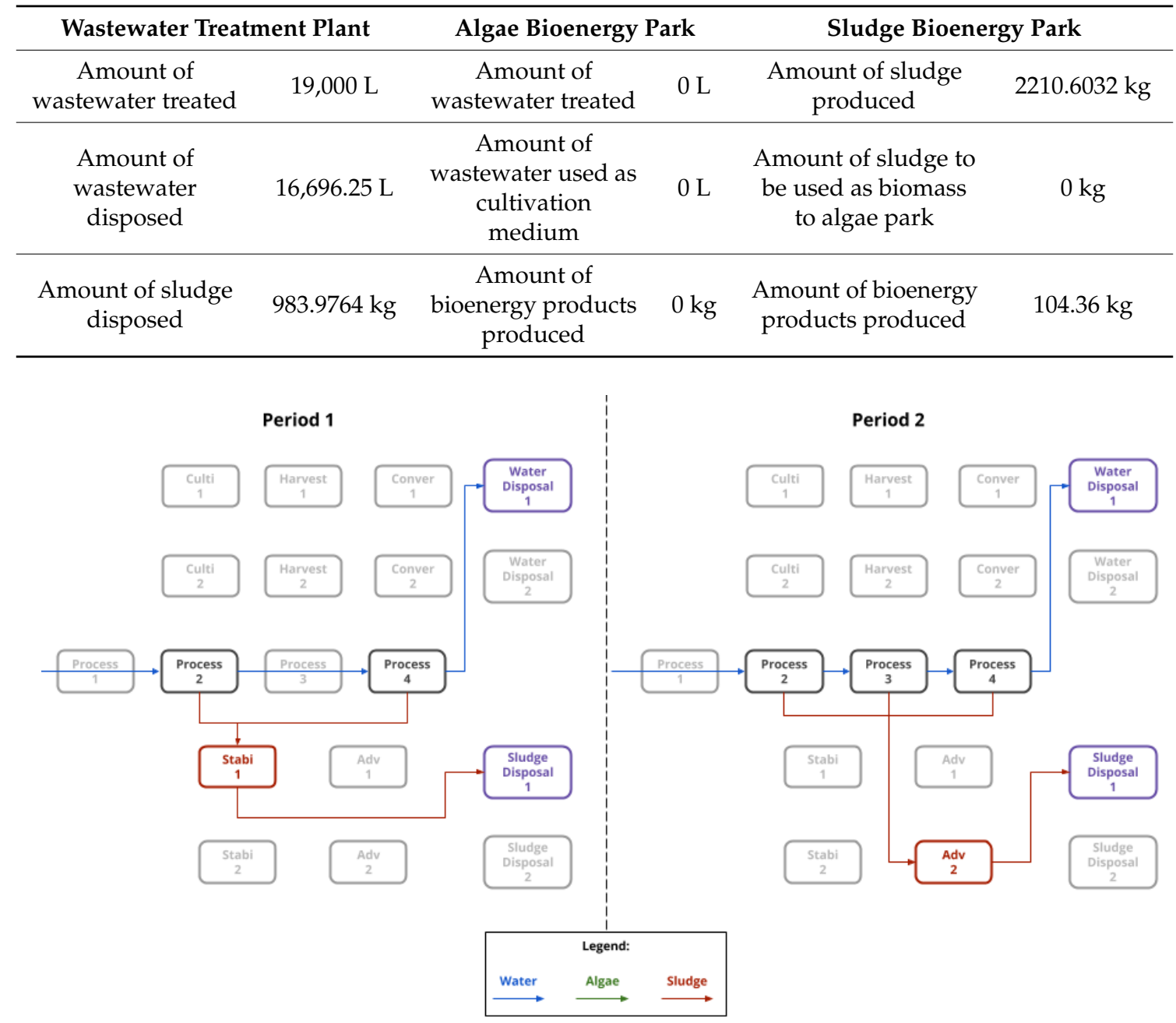

Figure 3. Treatment Network of Scenario with No Storage.

The two scenarios tested above were analyzed below. The cost slightly increased with the scenario with no storage allowed compared to the baseline scenario, as shown in Figure 4. Although no holding cost was incurred for with the restriction of storages, it also had an impact on the potential increase in profit by combining the sludge and algae biomass, which slightly increased the economic component overall. In terms of the environmental objective, higher carbon emissions were obtained when no storage was allowed. Solely relying on the WTS for treating the wastewater demand highly affects the objective compared to having the option to use the microalgae treatment. Emissions of both the baseline and no storage scenarios are shown in Figure 5. 


\section{2,000}

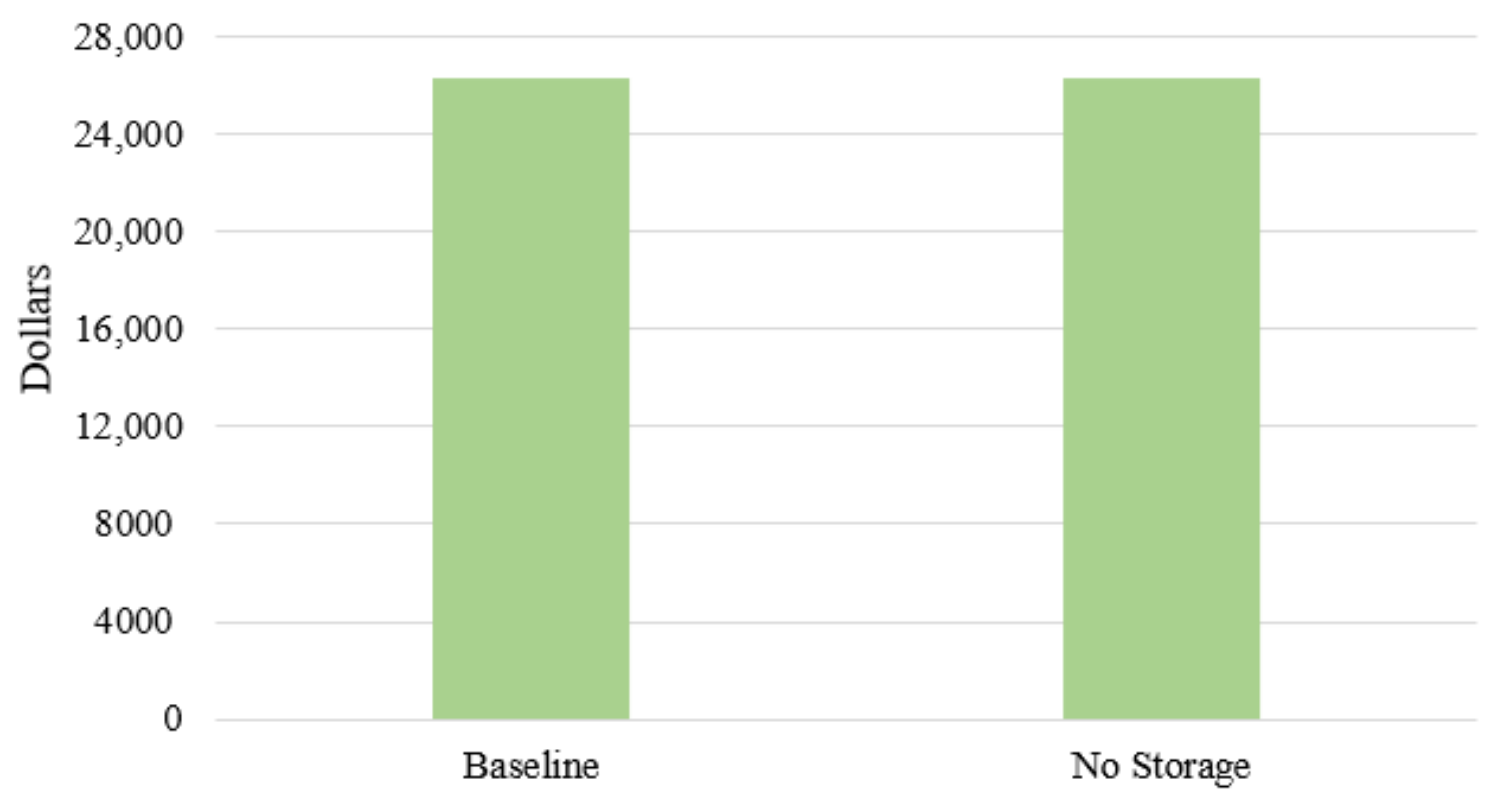

Figure 4. Comparison of Optimal Cost Results.

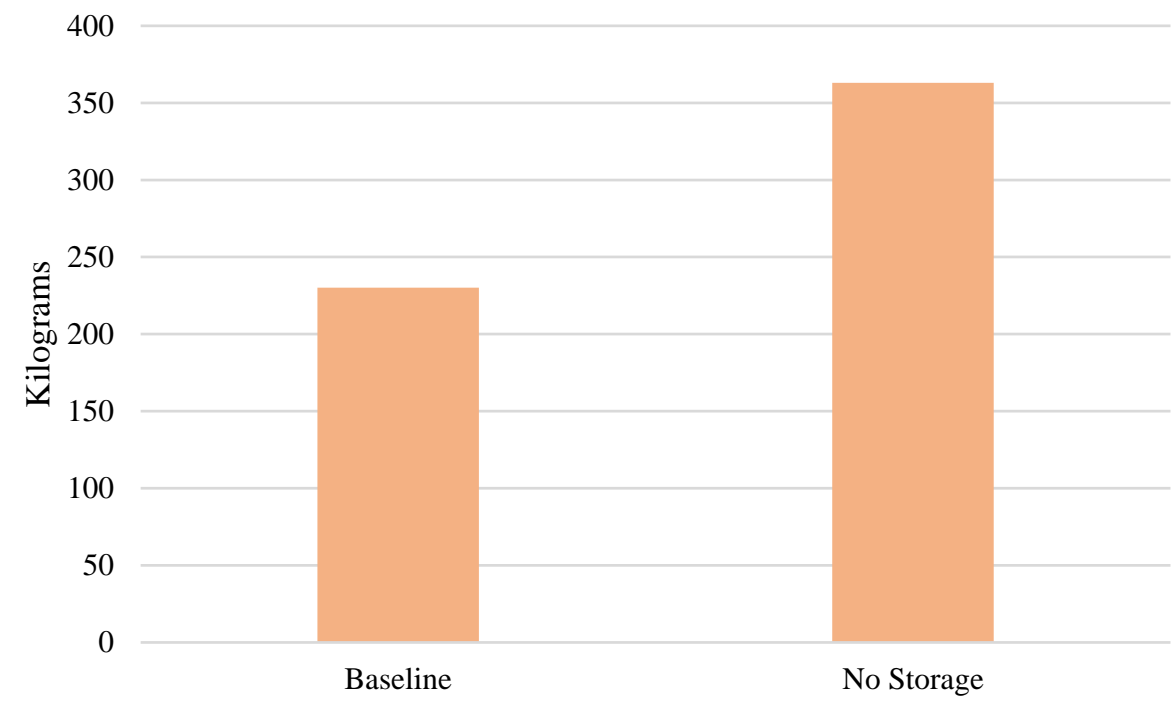

Figure 5. Comparison of Optimal Emissions Results.

\section{Scenario Analysis}

Due to the nature of uncertainty of available resources such as wastewater and inputs, a scenario analysis was done through sensitivity analysis. The sensitivity analysis varied the demand with increments of $5 \%$ starting from $-20 \%$ up to $+20 \%$. As seen on Figure 6 , the behavior of the costs relative to the percent increase of the demand. Decreasing the current demand by up to $20 \%$ yielded lower costs linearly. This is expected since all facilities involved would have less resources to use and process, with less savings to produce. In the portion of increasing demand, once it was increased by $5 \%$, it had a slight decrease in costs and continued to spike up linearly. The slight decrease came from the cultivation variable choosing to store the excess instead of directly processing it all at once. During the following period, it processed and mixed with the new inputs and chose to produce algae and energy with the more expensive energy conversion options, as these options yield more bioenergy 
products. This continues as demand increases to $20 \%$ as long as capacities for cultivation and processes are large enough to accommodate these inputs, since this would save enough processing costs.

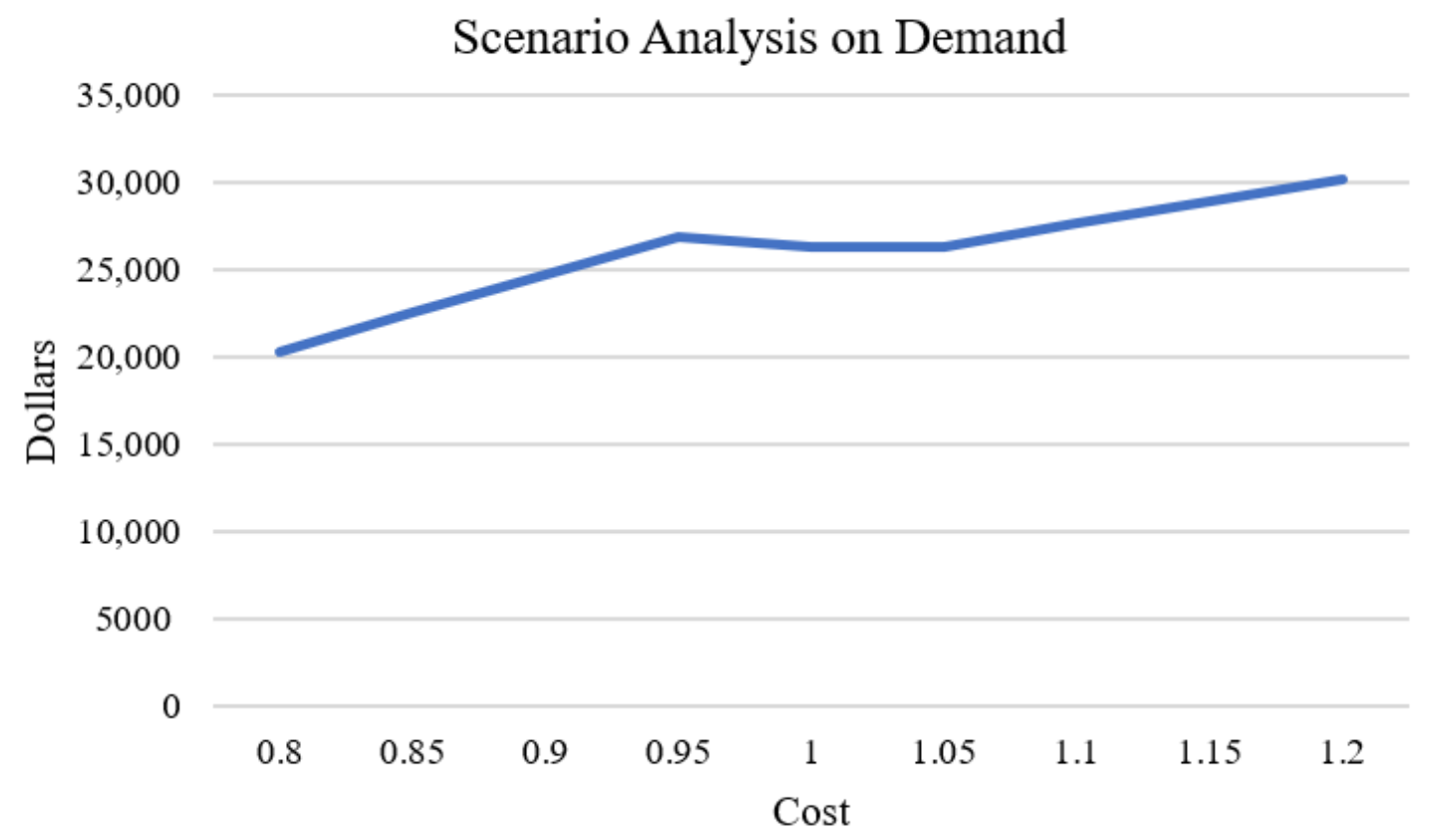

Figure 6. Sensitivity Analysis of Demand.

Due to the nature of inventory costs, the changes in prices were also analyzed over time as shown in Figure 7. The costs were increased and decreased by $20 \%$ from the original inventory costs, in increments of $5 \%$ each. Unlike demand which changed its behavior midway, inventory costs showed a linear progression over time as costs increased. The results did not change from the preceding time period, which means costs have to be significantly large to change from the original decision variables.

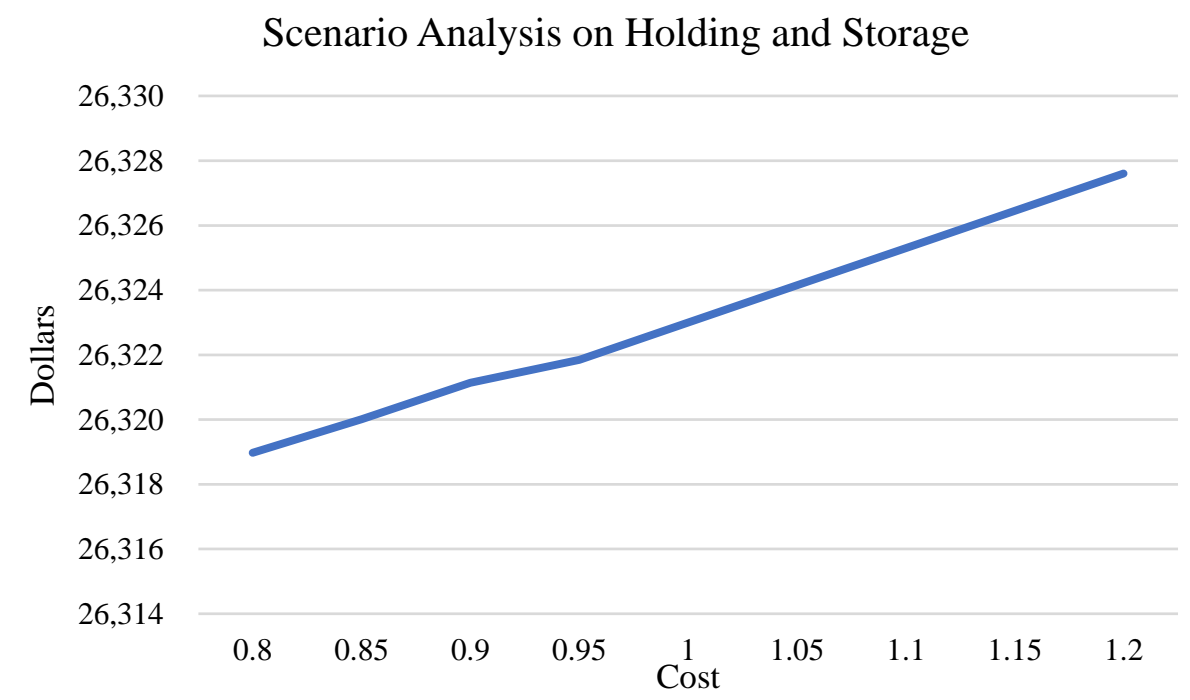

Figure 7. Sensitivity Analysis of Storage Costs.

\section{Conclusions}

The study has proposed a multi-objective optimization model for integrating wastewater treatment systems and sludge and algae-based bioenergy parks that considers water and sludge quality before 
discharging them from their respective facilities. The model can be used by stakeholders in finding the best processes to utilize in an integrated system that could treat the wastewater demand and sludge generated while minimizing both economic costs and carbon emissions. It will encourage treatment providers to consider a flexible treatment system rather than sticking to the traditional wastewater and sludge treatment by showing them the benefits in terms of costs and emissions. The system contains alternative treatments for wastewater and sludge to manage the uncertainty in the quality and volume of the incoming water. Solely optimizing either a cost or environmental objective could lead to high value for the other due to the conflicting nature between the two objectives, thus goal programming methodology was utilized to strike a balance between the two components. In running the baseline model with dual objective optimization, the whole system was able to incur a cost of $26,323.14$ dollars and carbon emissions of $230.17 \mathrm{~kg}$ and was able to utilize the three plants. A scenario wherein no storage was allowed was conducted to see the effect on the objective functions if no water exchanges between facilities for treatment would be considered, or co-processing of algae and sludge biomass. With this scenario, the cost incurred reached 26,347.85 dollars and there were carbon emissions of $362.99 \mathrm{~kg}$. The slight increase in cost when no storage was allowed was attributed to lower profits provided by sludge alone compared to combined microalgae and sludge. Having no storage immensely increased the overall carbon emission, since generally, the emissions of the processes in the wastewater treatment plant are relatively higher compared to those in the algae bioenergy park. Increasing the demand of inputs also causes a change in behavior of the model. The model would utilize the storage and process the input during the following period to fill up the capacity of processes to lessen costs (as seen in Figure 6). Additionally, changes in inventory costs were investigated over time and showed that the results remained the same even if costs were gradually increased, resulting in a linear proportion with time (as seen in Figure 7). Thus, inventory costs would have to increase significantly in order for storage to be unnecessary.

Future works may include the effect of storing microalgae and sludge biomass on biomass quality for future processing in accommodating different energy demands for each period. Moreover, the parameters used in the study are literature-based and may be too optimistic compared to the actual production. As such, the combined energy production for biomass may vary depending on the ratio of microalgae and sludge that needs to be added. Different pathways may also be available for water and sludge treatment, while other processes for microalgae cultivation and energy conversion may be available that could be added in a future study.

Author Contributions: Conceptualization, J.L.S.J.; Data Curation, C.J.C., M.M.G., and J.M.; Formal Analysis, C.J.C., M.M.G., and J.M., Supervision, A.P.M., J.L.S.J., C.S., A.C., and A.U.; Validation, C.J.C., M.M.G., and J.M.; Writing-original draft, C.A.C., M.M.G., and J.M.; Writing-Review, C.J.C., M.M.G., J.M., A.P.M., J.L.S.J., C.S., A.C., and A.U. All authors have read and agreed to the published version of the manuscript.

Funding: This research received no external funding.

Acknowledgments: The authors wish to acknowledge the financial support from the Office of the Vice Chancellor of Research and Innovation of De La Salle University.

Conflicts of Interest: The authors declare no conflict of interest.

\section{Appendix A}

Table A1. Quality requirements.

\begin{tabular}{cccc}
\hline Quality Type & Quality Requirement & Quality Type & Quality Requirement \\
\hline BOD & 70 & $\mathrm{P}$ & 5 \\
$\mathrm{~N}$ & 14 & VS (sludge) & 90 \\
\hline
\end{tabular}


Table A2. Microalgae Cell Rate Production.

\begin{tabular}{|c|c|c|c|c|c|c|}
\hline & \multicolumn{6}{|c|}{ Cultivation System } \\
\hline & \multicolumn{3}{|c|}{ Open } & \multicolumn{3}{|c|}{ Closed } \\
\hline & $\mathbf{N}$ & $\mathbf{P}$ & VS & $\mathbf{N}$ & $\mathbf{P}$ & VS \\
\hline Floating & 0.00012 & 0.00012 & 0.00012 & 0.00013 & 0.00013 & 000013 \\
\hline Flotation & 0.0009 & 0.0009 & 0.0009 & 0.00012 & 0.00012 & 0.00012 \\
\hline
\end{tabular}

Table A3. Quality Improvement Rate for Water.

\begin{tabular}{cccc}
\hline \multicolumn{5}{c}{ BOD } & $\mathbf{N}$ & $\mathbf{P}$ \\
\hline \multicolumn{4}{c}{ Wastewater treatment } \\
\hline plant \\
Pretreatment & 0.54 & 0.54 & 0.56 \\
Primary treatment & 0.7 & 0.7 & 0.82 \\
Secondary treatment & 0.4 & 0.4 & 0.34 \\
Tertiary treatment & 0.08 & 0.08 & 0.13 \\
\hline \multicolumn{5}{c}{ Cultivation system } \\
\hline Closed & 0.7 & 0.28 & 0.3 \\
Open & 0.7 & 0.28 & 0.3 \\
\hline \multicolumn{5}{c}{ Harvesting option } \\
\hline Floating & 0.02 & 0.01 & 0.01 \\
Filtration & 0.01 & 0.01 & 0.01 \\
\hline
\end{tabular}

Table A4. Quality Improvement Rate for Sludge.

\begin{tabular}{cccc}
\hline Process & VS & Process & VS \\
\hline Anaerobic digestion & $25.1 \%$ & Incineration & $95 \%$ \\
Aerobic digestion & $25.1 \%$ & Pyrolysis & $69 \%$ \\
\hline
\end{tabular}

Table A5. Energy Production Rate.

\begin{tabular}{cccccccc}
\hline & \multicolumn{2}{c}{ Microalgae } & & \multicolumn{2}{c}{ Sludge } & \multicolumn{2}{c}{ Co-Processing } \\
& Biodiesel & Biogas & & Biodiesel & Biogas & Biodiesel & Biogas \\
\hline \multirow{2}{*}{ Anaerobic digestion } & 0.42 & 0.25 & $\begin{array}{c}\text { Aerobic } \\
\text { digestion }\end{array}$ & 0.20 & 0.20 & 0.33 & 0.3628 \\
Gasification & 0.42 & 0.25 & $\begin{array}{c}\text { Incineration } \\
\text { Pyrolysis }\end{array}$ & 0.05 & 0.0299 & $0 . .05$ & 0.0299 \\
& & & Pyn & 0.1501 & 0.58 & 0.216 \\
\hline
\end{tabular}

Table A6. Cost parameter.

\begin{tabular}{|c|c|}
\hline \multicolumn{2}{|c|}{ Wastewater Treatment Facility } \\
\hline Pretreatment & 0.42 \\
\hline Primary treatment & 0.65 \\
\hline Secondary treatment & 0.37 \\
\hline Tertiary treatment & 0.3 \\
\hline \multicolumn{2}{|c|}{ Microalgae Bioenergy Park } \\
\hline \multicolumn{2}{|c|}{ Cultivation system } \\
\hline Closed & 0.8 \\
\hline Open & 0.7 \\
\hline
\end{tabular}


Table A6. Cont.

\begin{tabular}{cc}
\hline \multicolumn{2}{c}{ Harvesting option } \\
\hline Floating & 0.1 \\
Filtration & 0.2 \\
\hline \multicolumn{2}{c}{ Conversion option } \\
\hline Anaerobic digestion & 2 \\
Gasification & 1.9 \\
\hline \multicolumn{2}{c}{ Sludge Bioenergy Park } \\
\hline \multicolumn{2}{c}{ Stabilization process } \\
\hline Anaerobic digestion & 2 \\
Aerobic digestion & 2 \\
\hline Advanced treatment process \\
\hline Incineration & 1.75 \\
Pyrolysis & 2.1 \\
\hline \multicolumn{2}{c}{ Other Costs } \\
\hline Wastewater disposal \\
Sludge disposal \\
Freshwater cost \\
Holding cost \\
\hline \multicolumn{2}{c}{0.01} \\
\hline
\end{tabular}

Table A7. Emission Parameter.

\begin{tabular}{cc}
\hline Process & Emission \\
\hline Wastewater treatment processes & 0.007 \\
Cultivation system-Open/Closed & 0 \\
Harvesting option-Floating & 0.0001 \\
Harvesting option-Filtration & 0.0002 \\
Conversion option-Anaerobic digestion/Gasification & 0.04 \\
Stabilization Option-Anaerobic/Aerobic digestion & 0.04 \\
Advanced Treatment-Incineration & 0.08 \\
Advanced Treatment-Pyrolysis & 0.04 \\
Water disposal & 0.0005 \\
Sludge disposal & 0.0005 \\
\hline
\end{tabular}

\section{References}

1. The International Energy Agency. Electricity Generation by Fuel and Scenario, 2018-2040. 2019. Available online: https://www.iea.org/fuels-and-technologies/electricity (accessed on 30 June 2020).

2. Smith, C.J.; Forster, P.M.; Allen, M.; Fuglestvedt, J.; Millar, R.J.; Rogelj, J.; Zickfeld, K. Current fossil fuel infrastructure does not yet commit us to $1.5^{\circ} \mathrm{C}$ warming. Nat. Commun. 2019, 10, 101. [CrossRef] [PubMed]

3. Butturi, M.A.; Lolli, F.; Sellitto, M.A.; Balugani, E.; Gamberini, R.; Rimini, B. Renewable energy in eco-industrial parks and urban-industrial symbiosis: A literature review and a conceptual synthesis. Appl. Energy 2019, 255, 113825. [CrossRef]

4. Culaba, A.B.; Lim Ching, P.; San Juan, J.L.G.; Philip Mayol, A.; Sybingco, E.; Ubando, A.T. A Dynamic Sustainability Assessment of Algal Biorefineries for Biofuel Production. In Proceedings of the 2019 IEEE 11th International Conference on Humanoid, Nanotechnology, Information Technology, Communication and Control, Environment, and Management, Laoag, Philippines, 29 November-1 December 2019; pp. 3-6. [CrossRef]

5. Kim, J.; Yoo, G.; Lee, H.; Lim, J.; Kim, K.; Kim, C.W.; Park, M.S.; Yang, J.W. Methods of downstream processing for the production of biodiesel from microalgae. Biotechnol. Adv. 2013, 31, 862-876. [CrossRef] [PubMed]

6. Cheah, W.Y.; Ling, T.C.; Show, P.L.; Juan, J.C.; Chang, J.S.; Lee, D.J. Cultivation in wastewaters for energy: A microalgae platform. Appl. Energy 2016, 179, 609-625. [CrossRef] 
7. Mateo-Sagasta, J.; Liqa, R.; Thebo, A. Wastewater: Economic asset in an urbanizing world. Wastewater Econ. Asset Urban. World 2015, 1-282. [CrossRef]

8. Oladejo, J.; Shi, K.; Luo, X.; Yang, G.; Wu, T. A review of sludge-to-energy recovery methods. Energies 2019, 12, 60. [CrossRef]

9. Benjamin, M.F.D.; Ubando, A.T.; Razon, L.F.; Tan, R.R. Analyzing the disruption resilience of bioenergy parks using dynamic inoperability input-output modeling. Environ. Syst. Decis. 2015, 35, 351-362. [CrossRef]

10. Wang, X.; Zhao, B.; Yang, X. Co-pyrolysis of microalgae and sewage sludge: Biocrude assessment and char yield prediction. Energy Convers. Manag. 2016, 117, 326-334. [CrossRef]

11. Mahdy, A.; Mendez, L.; Ballesteros, M.; González-Fernández, C. Algaculture integration in conventional wastewater treatment plants: Anaerobic digestion comparison of primary and secondary sludge with microalgae biomass. Bioresour. Technol. 2015, 184, 236-244. [CrossRef]

12. Di Chen, Y.; Li, S.; Ho, S.H.; Wang, C.; Lin, Y.C.; Nagarajan, D.; Chang, J.S.; Ren, N. Integration of sludge digestion and microalgae cultivation for enhancing bioenergy and biorefinery. Renew. Sustain. Energy Rev. 2018, 96, 76-90. [CrossRef]

13. Boix, M.; Montastruc, L.; Azzaro-Pantel, C.; Domenech, S. Optimization methods applied to the design of eco-industrial parks: A literature review. J. Clean. Prod. 2015, 87, 303-317. [CrossRef]

14. Tsai, J.C.C.; Chen, V.C.P.; Beck, M.B.; Chen, J. Stochastic dynamic programming formulation for a wastewater treatment decision-making framework. Ann. Oper. Res. 2004, 132, 207-221. [CrossRef]

15. Kim, D.; Bowen, J.D.; Ozelkan, E.C. Optimization of wastewater treatment plant operation for greenhouse gas mitigation. J. Environ. Manag. 2015, 163, 39-48. [CrossRef] [PubMed]

16. Ang, M.; Duyag, J.; Tee, K.; Sy, C. A multiple input type optimization model integrating reuse and disposal options for a wastewater treatment facility. Chem. Eng. Trans. 2018, 70, 199-204. [CrossRef]

17. Campos, J.L.; Valenzuela-Heredia, D.; Pedrouso, A.; Val Del Río, A.; Belmonte, M.; Mosquera-Corral, A. Greenhouse Gases Emissions from Wastewater Treatment Plants: Minimization, Treatment, and Prevention. J. Chem. 2016, 2016, 1-12. [CrossRef]

18. Benjamin, M.F.D.; Tan, R.R.; Razon, L.F. A methodology for criticality analysis in symbiotic bioenergy parks. Energy Procedia 2014, 61, 41-44. [CrossRef]

19. Ng, R.T.L.; Ng, D.K.S.; Tan, R.R. Optimal planning, design and synthesis of symbiotic bioenergy parks. J. Clean. Prod. 2015, 87, 291-302. [CrossRef]

20. Wu, W.; Chang, J.S. Integrated algal biorefineries from process systems engineering aspects: A review. Bioresour. Technol. 2019, 291, 121939. [CrossRef]

21. Gupta, S.S.; Bhartiya, S.; Shastri, Y. Model-based optimisation of integrated algae biorefinery. IFAC Proc. Vol. 2014, 47, 1011-1018. [CrossRef]

22. Hoeltz, M.; Silvana, M.; Moraes, A.; Cassia, R.; Schneider, D.S. Microalgae: Cultivation techniques and wastewater phycoremediation. J. Environ. Sci. Health Part A Toxic Hazard. Subst. Environ. Eng. 2015, 50, 585-601. [CrossRef]

23. Ong, H.C.; Chen, W.H.; Farooq, A.; Gan, Y.Y.; Lee, K.T.; Ashokkumar, V. Catalytic thermochemical conversion of biomass for biofuel production: A comprehensive review. Renewable and Sustainable. Energy Rev. 2019, 113, 109266. [CrossRef]

24. García Prieto, C.V.; Ramos, F.D.; Estrada, V.; Villar, M.A.; Diaz, M.S. Optimization of an integrated algae-based biorefinery for the production of biodiesel, astaxanthin and PHB. Energy 2017, 139, 1159-1172. [CrossRef]

25. Culaba, A.B.; San Juan, J.L.; Ching, P.M.; Mayol, A.P.; Sybingco, E.; Ubando, A. Optimal synthesis of algal biorefineries for Biofuel production based on techno-economic and environmental efficiency. In Proceedings of the 2019 IEEE 11th International Conference on Humanoid, Nanotechnology, Information Technology, Communication and Control, Environment, and Management, Laoag, Philippines, 29 November1 December 2019. [CrossRef]

26. Solis, C.A.; Mayol, A.P.; San Juan, J.G.; Ubando, A.T.; Culaba, A.B. Multi-objective optimal synthesis of algal biorefineries toward a sustainable circular bioeconomy. IOP Conf. Ser. Earth Environ. Sci. 2020, 463, 6-12. [CrossRef]

27. Caligan, C.J.A.; Garcia, M.M.S.; Mitra, J.L.; Mayol, A.P.; San Juan, J.L.G.; Culaba, A.B. Multi-objective optimization of water exchanges between a wastewater treatment facility and algal biofuel production plant. IOP Conf. Ser. Earth Environ. Sci. 2020, 463. [CrossRef] 
28. Cao, Y.; Pawłowski, A. Sewage sludge-to-energy approaches based on anaerobic digestion and pyrolysis: Brief overview and energy efficiency assessment. Renew. Sustain. Energy Rev. 2012, 16, 1657-1665. [CrossRef]

29. Mills, N.; Pearce, P.; Farrow, J.; Thorpe, R.B.; Kirkby, N.F. Environmental \& economic life cycle assessment of current \& future sewage sludge to energy technologies. Waste Manag. 2014, 34, 185-195. [CrossRef]

30. Lam, C.M.; Hsu, S.C.; Alvarado, V.; Li, W.M. Integrated life-cycle data envelopment analysis for technoenvironmental performance evaluation on sludge-to-energy systems. Appl. Energy 2020, 266, 114867. [CrossRef]

31. Vadenbo, C.; Hellweg, S.; Guillén-Gosálbez, G. Multi-objective optimization of waste and resource management in industrial networks-Part I: Model description. Resour. Conserv. Recycl. 2014, 89, 52-63. [CrossRef]

32. Jiao, F.; Zhang, L.; Dong, Z.; Namioka, T.; Yamada, N.; Ninomiya, Y. Study on the species of heavy metals in MSW incineration fly ash and their leaching behavior. Fuel Process. Technol. 2016, 152, 108-115. [CrossRef]

33. Domínguez, A.; Menéndez, J.A.; Inguanzo, M.; Pís, J.J. Production of bio-fuels by high temperature pyrolysis of sewage sludge using conventional and microwave heating. Bioresour. Technol. 2006, 97, 1185-1193. [CrossRef]

34. Amoatey, P.; Bani, R. Wastewater Management. In Waste Water-Evaluation and Management; InTech: London, UK, 2011.

35. Amenorfenyo, D.K.; Huang, X.; Zhang, Y.; Zeng, Q.; Zhang, N.; Ren, J.; Haung, Q. Microalgae Brewery Wastewater Treatment: Potentials, Benefits and the Challenges. Int. J. Environ. Res. Public Health 2019, 16, 1910. [CrossRef] [PubMed]

36. Xu, H.; Li, Y.; Hua, D.; Zhao, Y.; Mu, H.; Chen, H.; Chen, G. Enhancing the anaerobic digestion of corn stover by chemical pretreatment with the black liquor from the paper industry. Bioresour. Technol. 2020, 306. [CrossRef] [PubMed]

37. Rollan, C.D.; Li, R.; San Juan, J.L.; Dizon, L.; Ong, K.B. A planning tool for tree species selection and planting schedule in forestation projects considering environmental and socio-economic benefits. J. Environ. Manag. 2018, 206, 319-329. [CrossRef] [PubMed]

38. Oosterkamp, W.J. Use of Volatile Solids from Biomass for Energy Production. In Bioenergy Research: Advances and Applications; Elsevier: Amsterdam, The Netherlands, 2014; pp. 203-217. [CrossRef]

39. Canziani, R.; Spinosa, L. Sludge from wastewater treatment plants. In Industrial and Municipal Sludge; Butterworth-Heinemann: Oxford, UK, 2019. [CrossRef] 